Published in final edited form as:

Methods Enzymol. 2006 ; 419: 149-179.

\title{
Hematopoietic Stem Cells
}

\section{ROBERT G. HAWLEY, ALI RAMEZANI, and TERESA S. HAWLEY}

\begin{abstract}
Hematopoietic stem cells (HSCs) have the capacity to self-renew and the potential to differentiate into all of the mature blood cell types. The ability to prospectively identify and isolate HSCs has been the subject of extensive investigation since the first transplantation studies implying their existence almost 50 years ago. Despite significant advances in enrichment protocols, the continuous in vitro propagation of human HSCs has not yet been achieved. This chapter describes current procedures used to phenotypically and functionally characterize candidate human HSCs and initial efforts to derive permanent human HSC lines.
\end{abstract}

\section{Introduction}

Hematopoietic stem cells (HSCs) are multipotent precursors that have self-renewal capacity and the ability to regenerate all of the different cell types that comprise the blood-forming system (Bonnet, 2002; McCulloch and Till, 2005). Transplantation of HSCs forms the basis of consolidation therapy in cancer treatments and is used to cure or ameliorate a number of hematologic and genetic disorders (Shizuru et al., 2005; Steward and Jarisch, 2005). With certain caveats (McCormack and Rabbitts, 2004), HSCs are also an attractive target cell population for gene therapies because they are readily accessible for ex vivo genetic modification and allow for the possibility of sustained transgene expression in circulating peripheral blood cells throughout the lifetime of an individual (Hawley, 2001; Moayeri et al., 2005).

Historically, mouse HSCs were identified retrospectively by utilizing clonal in vivo assays wherein labeled cells (e.g., genetically-tagged with reporter genes) were assessed for potential to functionally reconstitute hematopoiesis following injection into conditioned hosts, with selfrenewal capacity demonstrated by serial transfer into secondary recipients (Abramson et al., 1977; Capel et al., 1990; Jordan and Lemischka, 1990; Keller et al., 1985). Limiting dilution analysis of total bone marrow preparations allowed quantitative estimation of $\mathrm{HSC}$ frequencies ranging from 1 in 10,000 to 1 in 100,000 cells (Harrison et al., 1993; Harrison, 1980; Szilvassy et al., 1990). A major advance in the field of HSC biology was the prospective isolation of enriched populations of mouse HSCs based on cell surface phenotype (Spangrude et al., 1988). With the exception of clinical gene marking trials (Stewart et al., 1999), analogous HSC transplantation experiments cannot be performed in humans. For this reason, xenogeneic transplant models have been developed as surrogate assays to evaluate human hematopoietic precursors for in vivo repopulating potential. These assays have helped to elucidate the composition of the human HSC compartment (Bhatia et al., 1998; Gallacher et al., 2000; Glimm et al., 2001; Guenechea et al., 2001; Mazurier et al., 2003; Wang et al., 2003; Zanjani et al., 1998) and have provided paradigms for translation to clinical applications (Baum et al., 1992; Civin et al., 1996b; Lang et al., 2004; Shizuru et al., 2005; Shmelkov et al., 2005; Shpall et al., 1994; Yin et al., 1997).

Correspondence: Robert G. Hawley, Department of Anatomy and Regenerative Biology, The George Washington University Medical Center, 2300 I Street NW, Washington, DC 20037, USA; Phone: 202-994-3511; Fax: 202-994-8885; E-mail: rghawley@ gwu.edu. 
In this chapter, we discuss the phenotypic and functional characteristics of mouse and human HSCs, and describe protocols for the isolation and assay of candidate human HSCs. A procedure to derive factor-dependent human hematopoietic progenitor cell lines is also provided.

\section{Identification and Enrichment of HSCs}

\section{Cell Surface Markers}

All HSC activity in adult mouse bone marrow is contained in a population of cells characterized by expression of the c-Kit tyrosine kinase receptor (the receptor for stem cell factor, SCF), stem cell antigen-1 (Sca-1, Ly-6A/E), low levels of the Thy-1.1 cell surface antigen (Thy-1.1 ${ }^{\mathrm{lo}}$ ), and no or low levels of expression of many cell surface antigens found on differentiated cells belonging to various lineages (referred to as lineage-negative or $\mathrm{Lin}^{-}$) (Shizuru et al., 2005). Mouse HSCs variably express the sialomucin CD34, depending on developmental stage and cell cycle status (Ito et al., 2000; Matsuoka et al., 2001; Osawa et al., 1996; Sato et al., 1999). Recent studies have identified a number of additional cell surface antigens that mark mouse HSCs including: the Tie family of receptor tyrosine kinases (Arai et al., 2004; Iwama et al., 1993); endoglin, an ancillary transforming growth factor- $\beta$ receptor (Chen et al., 2002); endomucin, a CD34-like sialomucin (Matsubara et al., 2005); CD150, the founding member of the SLAM family of receptors (Kiel et al., 2005; Yilmaz et al., 2006); CD201, the endothelial protein C receptor (Balazs et al., 2006); and prion protein (Zhang et al. 2006b). The receptor for thrombopoietin (TPO), c-Mpl, is also expressed on $\sim 70 \%$ of mouse c-Kit ${ }^{+}$in $^{-}$Sca-1 ${ }^{+}$HSCs (Solar et al., 1998).

In humans, clinical protocols involving enrichment for HSCs generally utilize cells expressing CD34 (Civin et al., 1996b; Shizuru et al., 2005; Shpall et al., 1994), which is expressed on $\sim 0.2-3 \%$ of the nucleated cells in cord blood, bone marrow and mobilized peripheral blood (Civin et al., 1984; Krause et al., 1996; Sutherland et al., 1996). Experimentally, further isolation and characterization of $\mathrm{Lin}^{-} \mathrm{CD} 34^{+}$subpopulations have defined more primitive precursors with hematopoietic repopulating activity that express combinations of the CD59 surface antigen related to Sca-1, the vascular endothelial growth factor receptor-2 (VEGFR2 or KDR), and low levels of c-Kit (CD117), Thy-1 (CD90), and the CD38 surface antigen (Baum et al., 1992; Civin et al., 1996a; Gunji et al., 1993; Hill et al., 1996; Kawashima et al., 1996; Larochelle et al., 1996; Ziegler et al., 1999). As in the mouse, the TIE family of receptor tyrosine kinases and the TPO receptor c-Mpl also appear to further enrich for human HSCs, being expressed on $\sim 80 \%$ and $\sim 70 \%$ of CD $34^{+} \mathrm{CD} 38^{-}$cells, respectively (Hashiyama et al., 1996; Ninos et al., 2006; Solar et al., 1998).

It has recently become appreciated that the CD133 cell surface antigen is another important human HSC marker (de Wynter et al., 1998; Gallacher et al., 2000; Hess et al., 2006; Lang et al., 2004; Shmelkov et al., 2005; Yin et al., 1997). CD133, the human homolog of mouse Prominin-1 (Shmelkov et al., 2005), was first identified as a selective human HSC surface molecule using a monoclonal antibody recognizing a particular glycosylated form of Prominin-1 designated as AC133 (Yin et al., 1997). Selection for $\mathrm{CD}^{133^{+}}$hematopoietic precursors yields $>90 \% \mathrm{CD} 34^{+}$cells and contains all of the human hematopoietic repopulating activity. Notably, the extremely rare CD34- ${ }^{-}$candidate HSCs that had previously been identified (Bhatia et al., 1998; Gao et al., 2001; Wang et al., 2003; Zanjani et al., 1998) reside within the CD133 fraction (Gallacher et al., 2000).

Enriched populations of human HSCs are routinely obtained by positive selection for CD34/ CD133 and/or by depletion of lineage-committed cells using monoclonal antibodies recognizing differentiation markers (such as CD2, CD3, CD14, CD16, CD19, CD24, CD41, CD56, CD66b and CD235a) in the context of immunomagnetic or fluorescence-activated cell 
sorting methodologies. In this regard, it is important to bear in mind that physical manipulation of HSCs during the enrichment procedure may not be without effect on cell physiology (Kimura et al., 2004). For example, it is conceivable that binding of antibodies to CD34/CD133 may trigger intracellular signaling pathways that could modulate HSC function. Interestingly, a recent study suggests that the majority of cells within the CD $34^{+} \mathrm{CD} 38^{-} \mathrm{Lin}^{-} \mathrm{HSC}$ compartment express the myeloid-associated lineage markers CD13, CD33 and CD123 (the low affinity binding subunit of the IL-3 receptor) (Taussig et al., 2005), indicating that some caution is warranted when selecting a cocktail of monoclonal antibodies for lineage marker-depletion enrichment of human HSCs.

\section{Fluorescent Dye Staining}

Hoechst $\mathbf{3 3 3 4 2}$ and Rhodamine 123-Other strategies that have been utilized to identify and enrich for HSCs are based on the staining patterns of fluorescent dyes (Bertoncello et al., 1985; Goodell et al., 1996; Jones et al., 1995; Leemhuis et al., 1996; Storms et al., 1999; Visser et al., 1981; Wolf et al., 1993). Rhodamine 123 (which preferentially accumulates in active mitochondria) and Hoechst 33342 (a bis-benzimidazole that binds to adenine-thymine rich regions of the minor groove of DNA) are two fluorescent vital dyes that have been routinely used to characterize hematopoietic precursor populations (Bertoncello et al., 1985; Leemhuis et al., 1996; McAlister et al., 1990; Visser et al., 1981; Wolf et al., 1993). Rhodamine 123 staining of mouse bone marrow cells demonstrated that HSCs with long-term repopulating potential stained dimly whereas more brightly staining hematopoietic precursors could only provide short-term repopulation (Bertoncello et al., 1988; Bertoncello et al., 1991; Spangrude and Johnson, 1990; Zijlmans et al., 1995). Moreover, subpopulations of mouse bone marrow cells that stained most weakly with both dyes were shown to be highly enriched for long-term repopulating HSCs (Bertoncello and Williams, 2004; Leemhuis et al., 1996; Wolf et al., 1993). Decreased staining with these dyes generally reflects a metabolically and mitotically inactive state (Arndt-Jovin and Jovin, 1977; Johnson et al., 1980; Spangrude and Johnson, 1990). However, it is now appreciated that decreased staining of HSCs with rhodamine 123 and Hoechst 33342 is also due to efflux mediated by at least two members of the ATP-binding cassette (ABC) family of transporters, $\mathrm{ABCB} 1$ (also referred to as MDR1 or P-glycoprotein) and ABCG2 (also referred to as BCRP, MXR or ABCP) (Chaudhary and Roninson, 1991; Juliano and Ling, 1976; Scharenberg et al., 2002; Zhou et al., 2001; Zhou et al., 2002).

Side Population Assay-A novel method that simultaneously monitors low fluorescence intensity of Hoechst 33342 staining at $\sim 450 \mathrm{~nm}$ and at $>675 \mathrm{~nm}$ following ultraviolet excitation identifies a rare $(<0.1 \%)$ subpopulation of mouse bone marrow cells, referred to as 'side population' (SP) cells, which contains the vast majority of long-term hematopoietic repopulating activity (Goodell et al., 1996). The ABC transporter Bcrp1 (the mouse ortholog of human ABCG2) expressed in mouse bone marrow cells is the major determinant of the mouse SP profile (Zhou et al., 2001; Zhou et al., 2002). Subsequent multiparameter flow cytometric analysis of mouse bone marrow SP cells showed that approximately one-third exhibited the $\mathrm{c}-\mathrm{Kit}^{+} \mathrm{Thy}-1.1^{\mathrm{lo}} \mathrm{Lin}^{-} \mathrm{Sca}-1^{+}$phenotype while approximately one-half expressed CD34 (Pearce et al., 2004). In another study, mouse bone marrow cells with the strongest dye efflux activity, which exhibited the highest hematopoietic repopulating activity, were shown to have a c-Kit ${ }^{+} \mathrm{Lin}^{-} \mathrm{Sca}-1^{+} \mathrm{CD} 34^{-}$phenotype (Matsuzaki et al., 2004).

The SP assay has also been applied to human hematopoietic tissues (Eaker et al., 2004; Goodell et al., 1997; Naylor et al., 2005; Preffer et al., 2002; Scharenberg et al., 2002; Storms et al., 2000; Uchida et al., 2001). Unlike mouse bone marrow SP cells, human hematopoietic SP cells constitute a much more phenotypically and functionally heterogeneous precursor population (Naylor et al., 2005; Preffer et al., 2002; Storms et al., 2000; Uchida et al., 2001). CD34- SP cells have been identified in several studies, but to date repopulating ability of human 
hematopoietic SP cells has only been demonstrated for $\mathrm{CD} 34^{+}$subpopulations (Eaker et al., 2004; Scharenberg et al., 2002; Uchida et al., 2001).

\section{Fluorescent Substrates for Cytosolic Aldehyde Dehydrogenase Activity-}

Cytosolic aldehyde dehydrogenase (ALDH), an enzyme responsible for oxidizing a variety of intracellular aldehydes, is expressed at high levels in HSCs, conferring resistance to the alkylating agents cyclophosphamide and 4-hydroxyperoxycyclophosphamide (Gordon et al., 1985; Kastan et al., 1990; Sahovic et al., 1988). Fluorescent substrates for ALDH have been developed and shown to be useful for isolating mouse and human HSCs (Fallon et al., 2003; Hess et al., 2006; Hess et al., 2004; Jones et al., 1996; Jones et al., 1995; Storms et al., 1999). In proof-of-principle studies (Jones et al., 1996; Jones et al., 1995), dansylaminoacetaldehyde (DAAA) was used as an ALDH substrate. DAAA can diffuse freely across the cell membrane because it is uncharged. Cells expressing ALDH oxidize DAAA to dansylglycine, which is retained intracellularly by virtue of a charged carboxylate group at physiologic $\mathrm{pH}$, and $\mathrm{ALDH}^{+}$cells are identified by dansyl fluorescence upon excitation with ultraviolet light. More recently, a newer fluorescent substrate for ALDH—termed BODIPY $^{\mathrm{TM}}$-aminoacetaldehyde (BAAA) — was synthesized, which uses a nontoxic visible light-excitable fluorophore BODIPY ${ }^{\mathrm{TM}}$ (Storms et al., 1999). Similar to DAAA, BAAA is uncharged and diffuses freely across the cell membrane, becoming converted to BODIPY ${ }^{\mathrm{TM}}$ aminoacetate (BAA), which is retained intracellularly because of its net negative charge in the presence of an inhibitor of the ABC transporter ABCB1 (Storms et al., 1999).

Mouse hematopoietic precursors enriched for high expression of ALDH by staining with BAAA or DAAA may represent a novel class of HSCs, which express undetectable or low levels of the c-Kit, Thy-1, Sca-1 and CD34 HSC markers, but which produce long-term albeit delayed multilineage engraftment (Armstrong et al., 2004; Jones et al., 1996). Flow cytometric analysis of human cord blood cells stained with BAAA identified a population of cells (at a frequency of $\sim 1 \%$ ) with bright fluorescence intensity $\left(\mathrm{ALDH}^{\mathrm{br}}\right.$ ) and low orthogonal light "side" scattering $\left(\mathrm{SSC}^{\mathrm{lo}}\right)$ comprising $\sim 74 \% \mathrm{CD} 34^{+}$cells and $\sim 46 \% \mathrm{CD} 34^{+} \mathrm{CD} 38^{\mathrm{lo} /}-$ cells, which was largely depleted of cells with mature T cell, natural killer cell, myeloid, erythroid and platelet lineage markers (Storms et al., 1999). The SSC ${ }^{\mathrm{lo}} \mathrm{ALDH}{ }^{\mathrm{br}}$ population still contained a small number of B cells however ( 12\%) (Storms et al., 1999). In another study, Lin ${ }^{-}$ depletion combined with selection for ALDH ${ }^{\text {br }}$ cells by BAAA staining demonstrated enrichment for hematopoietic precursors coexpressing CD133 and CD34 ( 73\%) and all of the hematopoietic repopulating activity in human cord blood preparations (Hess et al., 2004). A recent follow-up study by the same group reported that prospective selection of $\mathrm{ALDH}^{\mathrm{br}} \mathrm{Lin}^{-}$human cord blood cells for CD133 expression yields a population of primitive precursors that are primarily $\mathrm{CD} 34^{+}(\sim 95 \%)$ and which contains all long-term hematopoietic repopulating activity (Hess et al., 2006).

A two-step enrichment strategy for human HSCs combining positive selection for CD133 cells and assay for high level ALDH expression ( $\mathrm{SSC}^{\mathrm{lo}} \mathrm{ALDH}{ }^{\text {br }}$ cells) will be described here.

\section{Isolation of Candidate Human HSCs Protocol}

1. Obtain human cord blood, bone marrow or mobilized peripheral blood cells after informed consent in conformity with a human subjects protocol approved by an Institutional Review Board, or purchase from a commercial source (e.g., AllCells, Cambrex, StemCell Technologies). For human cord blood cells, dilute anticoagulated cord blood 1:3 with phosphate buffered saline (PBS) containing $0.6 \%$ anticoagulant citrate dextrose solution A (ACD-A, Sigma-Aldrich, Catalog number C3821). Layer $35 \mathrm{ml}$ of diluted cord blood over $12 \mathrm{ml}$ of Ficoll-Paque PLUS (GE Healthcare Life Sciences, Catalog number 17-1440-02). Centrifuge at $375 \mathrm{~g}$ for $30 \mathrm{~min}$ at room 
temperature $\left(22^{\circ}\right)$. Collect cells at the interface, dilute with PBS containing $0.6 \%$ ACD-A and centrifuge at $375 \mathrm{~g}$ for $10 \mathrm{~min}$ at $22^{\circ}$. Resuspend cells in erythrocyte lysing solution $\left(0.15 \mathrm{M} \mathrm{NH}_{4} \mathrm{Cl}, 1.0 \mathrm{mM} \mathrm{KHCO}_{3}, 0.1 \mathrm{mM}\right.$ EDTA, $\left.\mathrm{pH} 7.2-7.4\right)$ and incubate for $10 \mathrm{~min}$ at $22^{\circ}$. Centrifuge at $375 \mathrm{~g}$ for $10 \mathrm{~min}$ at $22^{\circ}$ and wash once in PBS.

2. Subsequent enrichment for cells expressing CD133 can be performed with the CD133 MicroBead Kit (Miltenyi Biotec, Catalog number 130-050-801) utilizing superparamagnetic beads conjugated to a monoclonal mouse anti-human CD133/1 antibody and a VarioMACS ${ }^{\mathrm{TM}}$ Separator (Miltenyi Biotec, Catalog number 130-090-282). Follow the manufacturer's recommendations and obtain $\sim 1 \times 10^{6}$ $\mathrm{CD} 133^{+}$cells $/ \mathrm{ml}$ with $>95 \%$ purity (if necessary, repeat the enrichment using a second MACS $^{\circledR}$ cell separation column).

3. Prepare aliquots of $\sim 5 \times 10^{4} \mathrm{CD} 133^{+}$cells $/ 50$ ul in PBS containing $2 \%$ fetal bovine serum (FBS) for staining individually with fluorochrome-conjugated anti-CD133/2 (which recognizes a different epitope than CD133/1), anti-CD34 and anti-CD38 monoclonal antibodies, as compensation controls: unstained; anti-CD133/2phycoerythrin (PE) (Miltenyi Biotec, Catalog number 130-090-853); anti-CD34peridinin chlorophyll protein (PerCP) (BD Biosciences Pharmingen, Catalog number 340430); and anti-CD38-allophycocyanin (APC) (BD Biosciences Pharmingen, Catalog number 555462). Incubate at $4^{\circ}$ for $20 \mathrm{~min}$. Add $2 \mathrm{ml}$ PBS containing 2\% FBS. Centrifuge at $375 \mathrm{~g}$ for $10 \mathrm{~min}$ at $4^{\circ}$. Decant supernatant and drain. Resuspend in $300 \mu$ PBS containing $2 \%$ FBS. Keep on ice until analysis.

4. Identification of $\mathrm{CD} 133^{+}$cells expressing high levels of ALDH activity can be facilitated by using a commercial kit for BAAA staining (StemCell Technologies, ALDEFLUOR ${ }^{\circledR}$ kit, Catalog number 01700$)$. Centrifuge $1 \times 10^{6} \mathrm{CD} 133^{+}$cells at 375 $g$ for $10 \mathrm{~min}$ at $25^{\circ}$. Decant supernatant and drain. Resuspend $\mathrm{CD} 133^{+}$cells in $1 \mathrm{ml}$ of proprietary ALDEFLUOR ${ }^{\circledR}$ assay buffer (containing an inhibitor of ABCB1 transporter efflux activity) with the ALDEFLUOR ${ }^{\circledR}$ reagent (BAAA-DA; BODIPY $^{\mathrm{TM}}$-aminoacetaldehyde diethyl acetal) according to the manufacturer's instructions. BAAA-DA is dissolved in dimethylsulfoxide and exposed to hydrochloric acid to convert it to the ALDH substrate BAAA. As BAAA diffuses freely across the cell membrane, all of the viable cells will be fluorescent. However, cells with high ALDH activity metabolize the substrate into BAA (BODIPY ${ }^{\mathrm{TM}}$ aminoacetate) containing a charged carboxylate group and become intensely fluorescent. Including an inhibitor of ABCB1 transporter efflux activity throughout the assay ensures retention of the fluorescent BAA compound within the cell. Cells incubated in the presence of diethylaminobenzaldehyde (DEAB), a potent ALDH inhibitor, provide a control for background BAA fluorescence.

5. Upon completion of the assay (30-60 min), stain aliquots of the cells with combinations of anti-CD133/2-PE, anti-CD34-PerCP and anti-CD38-APC at 2-8 ${ }^{\circ}$ as above. After $20 \mathrm{~min}$, centrifuge all samples at $375 \mathrm{~g}$ for $10 \mathrm{~min}$ at $4^{\circ}$. Decant supernatant and drain. Resuspend samples in ALDEFLUOR ${ }^{\circledR}$ assay buffer.

6. Analyze on a flow cytometer equipped with excitation wavelengths of $488 \mathrm{~nm}$ and $633 \mathrm{~nm}$. Detect scatter and fluorescence signals with: 488/10 bandpass (BP) filters for SSC and forward scatter signals, 530/30 BP for BAA fluorescence, 576/26 BP for anti-CD133-PE, 675/20 BP for anti-CD34-PerCP, and 660/20 BP for anti-CD38-APC signals.

7. Fluorescence activated cell sorting of $\mathrm{CD} 133^{+}$cells expressing the highest levels of ALDH activity enriches for candidate human HSCs with a predominantly $\mathrm{SSC}^{\mathrm{lo}} \mathrm{ALDH}{ }^{\mathrm{br}} \mathrm{CD} 133^{+} \mathrm{CD} 34^{+} \mathrm{CD} 38^{\mathrm{lo}}$ phenotype (Fig. 1). Note: Since dead and dying 
cells without intact cellular membranes cannot retain the fluorescent BAA derivative, only viable cells are identified by this method.

\section{Functional Characterization of Candidate HSCs}

\section{Surrogate In Vivo Assays}

Heterogeneity of the human HSC compartment and continued questions regarding cell surface phenotype necessitate the use of in vivo assays of HSC function (Baum et al., 1992; Bhatia et al., 1998; Dao et al., 2003; Dorrell et al., 2000; Gallacher et al., 2000; Glimm et al., 2001; Guenechea et al., 2001; Mazurier et al., 2003; Sieburg et al., 2006; Wang et al., 2003; Zanjani et al., 1998).

Several xenogeneic transplant models have been developed as surrogate assays of human hematopoietic repopulating cells. The preimmune fetal sheep transplant assay has emerged as a useful large animal model (Civin et al., 1996a; Zanjani et al., 1996). However, the majority of functional assays of human HSC activity involve transplantation into immunodeficient mice with varying degrees of residual natural immunity (Bhatia et al., 1997b; Bock et al., 1995; Cashman et al., 1997; Cheng et al., 1998; Gimeno et al., 2004; Glimm et al., 2001; Goldman et al., 1998; Guenechea et al., 2001; Hiramatsu et al., 2003; Hogan et al., 1997; Ishikawa et al., 2002; Ito et al., 2002; Kamel-Reid and Dick, 1988; Kollet et al., 2000; Kyoizumi et al., 1992; Lapidot et al., 1992; Larochelle et al., 1996; Lowry et al., 1996; Mazurier et al., 1999; McCune et al., 1991; Meyerrose et al., 2003; Nolta et al., 1994; Pflumio et al., 1996; Shultz et al., 2005; Traggiai et al., 2004; Vormoor et al., 1994; Wang et al., 1997). The most widely used of these small animal models is the NOD.CB17-Prkdscid mouse - nonobese diabetic (NOD) mice crossed with severe combined immunodeficient (SCID) mice (Bhatia et al., 1997b; Cashman et al., 1997; Hogan et al., 1997; Larochelle et al., 1996; Lowry et al., 1996; Pflumio et al., 1996; Shultz et al., 1995; Wang et al., 1997). NOD/SCID mice support human cell engraftment due to defective rearrangement of T cell receptor and immunoglobulin ( $\mathrm{Ig})$ genes, resulting in defects of functional $\mathrm{T}$ and $\mathrm{B}$ cells; they also have low levels of natural killer cell cytotoxic activity, functionally immature macrophages and an absence of hemolytic complement. Candidate HSCs collectively termed SCID-repopulating cells (SRCs) are scored positive for engraftment if $\sim 1 \% \mathrm{CD}^{+} 5^{+}$human cells or $>0.1 \%$ human DNA can be detected in the bone marrow of NOD/SCID recipients at or greater than 6 weeks post-transplantation. Under most conditions, the NOD/SCID xenograft assay does not require administration of exogenous human cytokines; however, a sublethal conditioning regimen of 250-400 cGy irradiation is necessary, and cytokine administration or co-administration of accessory cells facilitates engraftment at limiting doses (Bonnet et al., 1999). Under these conditions, the frequency of SRC in human cord blood cells was determined to be 1 in $9.3 \times 10^{5}$ mononuclear cells (Wang et al., 1997) and 1 in $617 \mathrm{CD}^{+} 4^{+} \mathrm{CD} 38^{-} \mathrm{Lin}^{-}$cells (Bhatia et al., 1997b). While both lymphoid and myeloid cell populations are found, a shortcoming of the NOD/SCID xenograft assay is the general lack of $\mathrm{T}$ cell development, and differentiation of human hematopoietic precursors is limited mainly to immature cells belonging to the B-cell and, to a lesser degree, myeloid lineages. Other disadvantages of the NOD/SCID mouse model include its high sensitivity to irradiation and relatively short life span ( $\sim 80 \%$ of female and $\sim 50 \%$ of male NOD/SCID mice develop lethal thymic lymphomas by 20 weeks of age).

Attempts to obtain an improved host for human HSC transplantion led to the development of a strain of immunodeficient mice in which the residual low natural killer activity present in the NOD/SCID mouse was eliminated by backcrossing the $\beta 2$ microglobulin null allele onto the NOD/SCID background (NOD/SCID/B2 ${ }^{-1-}$ ) (Kollet et al., 2000). NOD/SCID/B2 ${ }^{-1-}$ mice support a more than 11-fold higher level of SRC frequency than NOD/SCID mice, with transplantation of $\sim 8 \times 10^{4}$ human cord blood mononuclear cells resulting in mutlilineage differentiation in the mouse bone marrow (Kollet et al., 2000). The enhanced SRC frequency 
in NOD/SCID/B2 $\mathrm{m}^{-1-}$ mice is due to short-term repopulation by myeloid-restricted $\mathrm{CD} 34^{+} \mathrm{CD} 38^{+}$cells and a predominantly $\mathrm{CD} 34^{+} \mathrm{CD} 38^{-}$population that has broader lymphomyeloid differentiation potential but which does not efficiently engraft NOD/SCID mice (Glimm et al., 2001). A limitation of NOD/SCID/B2 $\mathrm{m}^{-/-}$mice is a relatively short life span due to earlier onset and increased incidence of thymic lymphomas (the mean life span of $\mathrm{NOD} / \mathrm{SCID} / \mathrm{B} 2 \mathrm{~m}^{-/-}$mice is $\sim 11$ weeks shorter than NOD/SCID mice) (Christianson et al., 1997). Recently, new NOD/SCID models for human HSC engraftment have been reported that lack a functional X-linked common cytokine receptor $\gamma$-chain gene $\left(\mathrm{NOD} / \mathrm{SCID} / \gamma_{\mathrm{c}}{ }^{-}\right.$) (Ito $e t$ al., 2002; Shultz et al., 2005; Yahata et al., 2002). NOD/SCID $/ \gamma_{\mathrm{c}}{ }^{-}$mice support $\sim 6$-fold higher percentages of human hematopoietic cells in the host bone marrow than NOD/SCID mice, with precursors developing into mature human $\mathrm{CD}^{+} \mathrm{CD}^{+}$and $\mathrm{CD}^{+} \mathrm{CD}^{+} \mathrm{T}$ cells, $\mathrm{Ig}^{+} \mathrm{B}$ cells, natural killer cells, myeloid cells and plasmacytoid dendritic cells. Notably, NOD/SCID $/ \gamma_{\mathrm{c}}{ }^{-}$ mice survive beyond 16 months of age and even after sublethal irradiation resist lymphoma development.

Other immunodeficient mouse models have been created by crossing mice with a deficient recombinase activating gene $2(\operatorname{Rag} 2)$ with mice harboring the $\gamma_{\mathrm{c}}$ cytokine receptor gene deletion (Gimeno et al., 2004; Goldman et al., 1998; Mazurier et al., 1999; Traggiai et al., 2004; Weijer et al., 2002). Rag $2^{-/} \gamma_{\mathrm{c}}{ }^{-}$mice are characterized by absence of all T cell, B cell and natural killer cell function and show no spontaneous lymphoma development. However, efficient human multilineage hematopoietic engraftment in $\mathrm{Rag}^{-/-} \gamma_{\mathrm{c}}{ }^{-}$mice with a mixed H-2 major histocompatibility locus background requires exogenous human cytokines (Mazurier $e t$ al., 1999).

As noted earlier, the TPO receptor c-Mpl is a selective marker of mouse and human HSCs (Hashiyama et al., 1996; Ninos et al., 2006; Solar et al., 1998). Consistent with this observation, TPO has been demonstrated to be an important HSC supportive factor (Alexander et al., 1996; Fox et al., 2002; Kaushansky, 2003a; Petzer et al., 1996; Solar et al., 1998) in addition to being the physiologic regulator of megakaryocytopoiesis and thrombopoieis (Kaushansky, 2003b). A recent report suggested that human TPO is a major limiting factor for multilineage outgrowth of human hematopoietic cells in NOD/SCID mice (Verstegen et al., 2003). To assess the effects of human TPO on hematopoietic engraftment of candidate human HSCs in Rag $2^{-1-} \gamma_{\mathrm{c}}{ }^{-}$mice, we generated human TPO-producing Rag $2^{-/-} \gamma_{\mathrm{c}}{ }^{-}$mice by lentiviral vectormediated transgenesis (Lois et al., 2002; Ma et al., 2003; Pfeifer et al., 2002; Punzon et al., 2004). A self-inactivating (SIN) HIV-1-based lentiviral vector, SINF-EF-hTPO-W, was developed that expresses the human TPO cDNA from an internal human elongation factor 1a (EF1 $\alpha$ ) promoter (Ramezani et al., 2000; Ramezani et al., 2003; Ramezani and Hawley, 2002a; Ramezani and Hawley, 2003). Concentrated vesicular stomatitis virus G glycoprotein (VSV-G)-pseudotyped lentiviral vector particles $\left(10^{8}\right.$ transducing units $\left./ \mathrm{ml}\right)$ were microinjected into the perivitelline space of single-cell $\mathrm{H}-2^{\mathrm{b}} \mathrm{Rag} 2^{-/} \gamma_{\mathrm{c}}{ }^{-}$embryos and implanted into pseudopregnant recipient $\mathrm{H}-2^{\mathrm{b}} \mathrm{Rag}^{-/-} \gamma_{\mathrm{c}}{ }^{-}$mice (Lois et al., 2002; Punzon et al., 2004; Ramezani and Hawley, 2002b). Polymerase chain reaction analysis of genomic tail DNA using a forward primer located within the EF1 $\alpha$ promoter and a reverse primer located within the human TPO cDNA was used to detect founder animals carrying the integrated transgene (H-2 $2^{\mathrm{b}} \mathrm{Rag} 2^{-/-} \gamma_{\mathrm{c}}{ }^{-}$-hTPO mice). Serum levels of human TPO in the founder mice ranged between 100-500 pg/ml (R. Behnam, M.B. Chase, S. Soukharev, A.R., and R.G.H., unpublished data). Human $\mathrm{CD} 34^{+}$hematopoietic cells were isolated from cord blood as described below and intravenously injected into sublethally irradiated ( $350 \mathrm{cGy}) \mathrm{H}-2^{\mathrm{b}}$ $\mathrm{Rag} 2^{-/} \gamma_{\mathrm{c}}{ }^{-}$-hTPO and control H-2 $2^{\mathrm{b}} \mathrm{Rag} 2^{-/} \gamma_{\mathrm{c}}{ }^{-}$mice. As a potential preclinical predictor of the rate of platelet recovery after transplantation and thus an indication of the quality of hematopoietic engraftment (Angelopoulou et al., 2004; Bruno et al., 2004; Perez et al., 2001; Yasui et al., 2003), human platelets were evaluated in peripheral blood from weeks 1 to 8 after transplantation. Human platelets were detected in the peripheral blood of $\mathrm{H}-2^{\mathrm{b}}$ 
Rag $2^{-/} \gamma_{\mathrm{c}}{ }^{-}$-hTPO but not control H-2 ${ }^{\mathrm{b}} \mathrm{Rag} 2^{-/-} \gamma_{\mathrm{c}}{ }^{-}$mice by week $3(1.2 \pm 0.8 \%)$, reaching 8 $\pm 2 \%$ at week 8 (Fig. 2). Flow cytometric analysis of nucleated peripheral blood cells revealed that all of the H-2 $2^{\mathrm{b}} \mathrm{Rag}_{2}{ }^{-1-} \gamma_{\mathrm{c}}-$-hTPO mice $(15 / 15)$ but none of the control H-2 $2^{\mathrm{b}} \mathrm{Rag} 2^{-1-} \gamma_{\mathrm{c}}{ }^{-}$ mice (0/6) engrafted with human hematopoietic cells $\left(17 \pm 7 \% \mathrm{CD} 45^{+}\right.$human cells at 6 weeks post-transplantation; Fig. 3A). Slightly higher engraftment levels were obtained in mice that received co-administration of $\mathrm{CD}^{-} 4^{-} \mathrm{Lin}^{+}$accessory cells (17\% vs 13\%). Of the engrafted $\mathrm{CD} 45^{+}$human hematopoietic cells, $13 \pm 2 \%$ were $\mathrm{CD} 19^{+}$cells belonging to the $\mathrm{B}$ cell lineage and $26 \pm 4 \%$ were $\mathrm{CD} 33^{+}$myeloid cells (Fig. 3B). In contrast to the negative results obtained with adult $\mathrm{H}-2^{\mathrm{b}} \mathrm{Rag} 2^{-1-} \gamma_{\mathrm{c}}{ }^{-}$recipients, transplantation of $\mathrm{CD} 34^{+}$human hematopoietic progenitor cells into sublethally irradiated $\mathrm{H}-2^{\mathrm{d}} \mathrm{Rag} 2^{-/-} \gamma_{\mathrm{c}}{ }^{-}$newborns leads to de novo development of T cells, B cells, natural killer cells, myeloid cells and plasmacytoid dendritic cells, formation of structured primary and secondary lymphoid organs, and production of functional immune responses (Gimeno et al., 2004; Traggiai et al., 2004).

\section{Human Hematopoietic Repopulating Cell Assay Protocol}

1. Isolate mononuclear cells from human cord blood as described in the previous section. Enrich for cells expressing CD34 with the CD34 MicroBead Kit (Miltenyi Biotec, Catalog number 130-046-703) utilizing superparamagnetic beads conjugated to a monoclonal mouse anti-human CD34 antibody and a VarioMACS ${ }^{\mathrm{TM}}$ Separator. Follow the manufacturer's recommendations and obtain $\sim 1 \times 10^{6} \mathrm{CD} 34^{+}$cells $/ \mathrm{ml}$ with $>95 \%$ purity (if necessary, repeat the enrichment using a second MACS $^{\circledR}$ cell separation column). Retain the $\mathrm{CD}^{-} 4^{-} \mathrm{Lin}^{+}$flow-through cells for co-administration as accessory cells.

2. All animal procedures are carried out in accordance with Institutional Animal Care and Use Committee guidelines. H-2 ${ }^{\mathrm{b}} \mathrm{Rag} 2^{-1-} \gamma_{\mathrm{c}}{ }^{-}((\mathrm{C} 57 \mathrm{BL} / 6 \mathrm{~J} \times \mathrm{C} 57 \mathrm{BL} / 10 \mathrm{SgSnAi})-$ $[\mathrm{KO}] \gamma_{\mathrm{c}}-[\mathrm{KO}]$ Rag2, Taconic, Catalog number 004111) and NOD/SCID (NOD.CB17Prkdc ${ }^{\text {scid }}$, The Jackson Laboratory, Catalog number 001303) immunodeficient mice are housed in sterile microisolator cages on laminar flow racks to minimize the chance of adventitious infections. Two to six hours prior to transplantation, the mice are exposed to a single sublethal dose of total body $\gamma$-irradiation from a ${ }^{137} \mathrm{Cs}$ source $(350$ cGy for $\mathrm{H}-2^{\mathrm{b}} \mathrm{Rag}^{-/-} \gamma_{\mathrm{c}}{ }^{-}$mice; $250 \mathrm{cGy}$ for NOD/SCID mice). Baytril (Bayer; active ingredient: enrofloxacin) is added to the drinking water $(2 \mathrm{ml} / 250 \mathrm{ml})$ immediately after irradiation and treatment is continued for 3 weeks as an additional prophylactic measure to prevent possible deaths due to adventitious infections.

3. Prepare aliquots of $\sim 5 \times 10^{5} \mathrm{CD} 34^{+}$cells with or without $1 \times 10^{6} \mathrm{CD} 34^{-} \mathrm{Lin}^{+}$cells (as accessory cells) in $200 \mu \mathrm{l} \mathrm{PBS}$ and transplant into sublethally irradiated 8- to 10week-old immunodeficient mice via intravenous tail vein injection using a 27 gauge needle.

4. Detection of human platelets in mouse peripheral blood: Mouse bleeding (from the retro-orbital venous sinus) is performed after inhalation isoflurane anesthesia and administration to the eye of one drop of a local anesthetic (Tetracaine Ophthalmic Solution, $0.5 \%$ solution; Phoenix Pharmaceutical). At weekly intervals posttransplantation, collect peripheral blood from the retro-orbital venous sinus using microhematocrit capillary tubes (Fisher Scientific, Catalog number 22-362-566) and place $\sim 100 \mu \mathrm{l}$ blood into micro-collection tubes containing potassium ethylenediaminetetraacetic (EDTA; Sarstedt, Catalog number 41.1395.105). Centrifuge at $1,500 \mathrm{~g}$ for $5 \mathrm{~min}$ at $22^{\circ}$ and resuspend the pellet in $500 \mu \mathrm{l}$ PBS containing $2 \%$ FBS. Stain $50 \mu \mathrm{l}$ aliquots of the cell/platelet suspension for $30 \mathrm{~min}$ at $22^{\circ}$ with the following monoclonal antibodies: fluorescein isothyocyanate (FITC)conjugated anti-human CD41a (BD Biosciences Pharmingen, Catalog number 555466) or FITC-conjugated mouse $\mathrm{IgG}_{1}$ isotype control (BD Biosciences 
Pharmingen, Catalog number 349041), and anti-mouse CD61-PE (BD Biosciences Pharmingen, Catalog number 553347) or PE-conjugated hamster $\mathrm{IgG}_{1}$ isotype control (BD Biosciences Pharmingen, Catalog number 553972). Centrifuge at $750 \mathrm{~g}$ for 5 $\mathrm{min}$ at $22^{\circ}$. Decant supernatant and drain. Wash in $2 \mathrm{ml}$ PBS containing $2 \%$ FBS plus $0.1 \% \mathrm{NaN}_{3}$. Centrifuge at $750 \mathrm{~g}$ for $5 \mathrm{~min}$ at $22^{\circ}$. Decant supernatant and drain. Resuspend in $500 \mu \mathrm{l}$ PBS containing $2 \%$ FBS plus $0.1 \% \mathrm{NaN}_{3}$. Platelets are analyzed on a flow cytometer equipped with excitation wavelengths of $488 \mathrm{~nm}$ and $633 \mathrm{~nm}$ by gating for low SSC and forward scatter signals (Perez et al., 2001).

5. Detection of human hematopoietic cells in mouse bone marrow: Mice are euthanized under inhalation isoflurane anesthesia by cervical dislocation at or greater than 6 weeks post-transplantation. Single-cell bone marrow suspensions are prepared by flushing the femurs and tibiae with PBS containing 2\% FBS using a 21-gauge needle. Erythrocytes are removed by hypotonic lysis in $0.15 \mathrm{M} \mathrm{NH}_{4} \mathrm{Cl}, 1.0 \mathrm{mM} \mathrm{KHCO}_{3}, 0.1$ mM EDTA, pH 7.2-7.4 (Eaker et al., 2004; Ramezani et al., 2000). Prepare aliquots of $\sim 1 \times 10^{5}$ cells $/ 100 \mu \mathrm{l}$ in PBS containing $2 \%$ FBS and stain as described in the previous section with the following monoclonal antibodies (all from BD Biosciences Pharmingen): anti-human CD45-FITC (Catalog number 555482), FITC-conjugated mouse $\mathrm{IgG}_{1}$ isotype control (Catalog number 349041), anti-human CD19-APC (Catalog number 555415), anti-human CD33-APC (Catalog number 551378) and APC-conjugated mouse IgG $_{1}$ isotype control (Catalog number 555751). As an additional negative control, stain the bone marrow from an untransplanted mouse. Incubate at $4^{\circ}$ for $20 \mathrm{~min}$. Add $1 \mathrm{ml}$ PBS containing $2 \%$ FBS plus $0.1 \% \mathrm{NaN}_{3}$. Centrifuge at $375 \mathrm{~g}$ for $10 \mathrm{~min}$ at $4^{\circ}$. Decant supernatant and drain. Resuspend in 500 $\mu \mathrm{PBS}$ containing 2\% FBS plus $0.1 \% \mathrm{NaN}_{3}$ and analyze by flow cytometry.

\section{Long-term Culture of Candidate HSCs and Progenitors}

\section{Overview}

Although a variety of culture conditions support some self-renewal of human hematopoietic progenitors, long-term maintenance of HSCs in vitro remains a major challenge to the field (Sauvageau et al., 2004). As illustrated in Fig. 4, a significant decrease in human hematopoietic repopulating activity in NOD/SCID mice was observed following in vitro culture of CD34 ${ }^{+}$ cord blood cells for 4 days in serum-free medium supplemented with a combination of SCF, TPO and Flt3 ligand (Larochelle et al., 1996; Petzer et al., 1996). However, modest expansion of SRC (2-to 6-fold net increases) has been reported after short-term culture in serum-free medium in more complex cocktails of hematopoietic growth factors (Bhatia et al., 1997a; Conneally et al., 1997; Gammaitoni et al., 2003). Evidence for a limited degree of in vitro expansion of candidate human HSCs has also been obtained under other culture conditions (Ando et al., 2006; Chute et al., 2005; Madlambayan et al., 2005; Piacibello et al., 1999; Ueda et al., 2000).

We have recently explored another approach based on the observation that human embryonic stem cells circumvent cellular senescence by expressing the catalytic subunit of telomerase reverse transcriptase, hTERT, a specialized ribonucleoprotein complex that is responsible for adding telomeric DNA (repetitive TTAGGG sequences) to the ends of chromosomes to prevent shortening during replication (Smogorzewska and de Lange, 2004; Thomson et al., 1998). Candidate human HSCs express relatively high levels of hTERT (Yui et al., 1998), and telomere length analysis of human HSC subpopulations indicates that cells with the longest telomeres have the greatest proliferative potential (Bartolovic et al., 2005; Van Ziffle et al., 2003). Conversely, patients with aplastic anemia have short telomeres and mutations in telomerase have been identified as the cause of hematopoietic failure (Vulliamy et al., 2001; Yamaguchi et al., 2005). Besides progressive telomere shortening, human cells undergo 
senescence in response to various types of stress (Campisi, 2005). Regardless of the senescence-initiating stimuli, the signaling pathways triggered converge to varying extents on the 553 and retinoblastoma $(\mathrm{Rb})$ tumor suppressors. Therefore, we employed HIV-1-based SIN lentiviral vectors to introduce the hTERT gene and the human papillomavirus type 16 (HPV16) E6 and E7 genes (Okamoto et al., 2002), which accelerate the degradation of p53 and Rb, respectively (Munger et al., 2004), into human $\mathrm{CD} 34^{+}$cord blood cells. The transduced $\mathrm{CD} 34^{+}$cells were then maintained under serum-free conditions in the presence of SCF, TPO and Flt3 ligand, with or without IL-3 (Akimov et al., 2005). Although this strategy did not result in the immortalization of human HSCs, several SCF-dependent cell lines resembling human myeloerythroid/mast cell progenitors were established in this manner, two of which express low levels of the HSC surface antigen CD133. It is important to point out, however, that the cell lines contain chromosomal aberrations (Table 1). Abnormal karyotypes notwithstanding, the progenitor cell lines were not leukemogenic when injected into sublethally-irradiated NOD/SCID mice (Akimov et al., 2005). These findings establish the feasibility of bypassing senescence in human hematopoietic progenitors through genetic engineering, providing proof-of-principle for approaches that might eventually lead to the establishment of permanent human HSC lines. Accordingly, our future efforts will focus on extending these results by assessing the combinatorial effects of novel hematopoietic growth factors such as Notch ligands, Hedgehog proteins, Wnt molecules, bone morphogenic proteins, HOXB4 homeoprotein, and angiopoietin-like proteins (Sauvageau et al., 2004; Zhang et al., 2006a).

\section{Derivation of Human Hematopoietic Progenitor Cell Lines Protocol}

1. The HIV-1-based SINF-MU3-hTERT-IRES-GFP-W-S and SINF-MU3-E6E7-IRESYFP-W-S lentiviral vectors used to immortalize human hematopoietic progenitors have been described previously (Akimov et al., 2005). SINF-MU3-hTERT-IRESGFP-W-S contains the hTERT cDNA upstream of an encephalomyocarditis virus internal ribosome entry site (IRES)-green fluorescent protein (GFP) gene cassette and SINF-MU3-E6E7-IRES-YFP-W-S contains the HPV16 E6/E7 coding region upstream of an IRES-yellow fluorescent protein (YFP) gene cassette. In both cases, transgene transcription is driven by an internal murine stem cell virus (MSCV) long terminal repeat (LTR) promoter (Hawley et al., 1994; Ramezani et al., 2000;

Ramezani et al., 2003).

2. Culture human embryonic kidney 293 T cells in Dulbecco's modified Eagle's medium (Invitrogen) supplemented with 10\% heat-inactivated FBS, 2 mM L-glutamine, 50 $\mathrm{IU} / \mathrm{ml}$ penicillin and $50 \mu \mathrm{g} / \mathrm{ml}$ streptomycin at $37^{\circ}$ in a humidified atmosphere containing $5 \% \mathrm{CO}_{2}$. Plate the $293 \mathrm{~T}$ cells $\left(4 \times 10^{6}\right)$ into 10 -cm tissue culture dishes containing $7 \mathrm{ml}$ of complete medium the day before transfection. Mix $15 \mu \mathrm{g}$ of the transfer vector plasmid (SINF-MU3-hTERT-IRES-GFP-W-S or SINF-MU3-E6E7IRES-YFP-W-S), $10 \mu \mathrm{g}$ of the packaging plasmid pCMV $\Delta$ R8.91 (Zufferey et al., 1997 ) and $5 \mu \mathrm{g}$ of the VSV-G glycoprotein envelope plasmid pMD.G (Naldini $e t$ al., 1996). Bring the volume up to $450 \mu \mathrm{l}$ with sterile water. Add $50 \mu \mathrm{l} 2.5 \mathrm{M} \mathrm{CaCl}_{2}$ and mix. Add the DNA/CaCl 2 solution dropwise to $500 \mu \mathrm{l}$ of $2 \times \mathrm{N}$-(2-Hydroxyethyl) piperazine-N'-2-ethanesulfonic acid (HEPES)-buffered saline $(0.283 \mathrm{M} \mathrm{NaCl}, 0.023$ M HEPES [Sigma-Aldrich, Catalog number H0887], $1.5 \mathrm{mM} \mathrm{Na}_{2} \mathrm{HPO}_{4}, \mathrm{pH} 7.05$ ) in a 15 -ml conical tube. Use a $5 \mathrm{ml}$ pipet to bubble the $2 \times$ HEPES-buffered saline while adding the DNA/CaCl 2 solution. Vortex immediately for 5 seconds and incubate for $20 \mathrm{~min}$ at $22^{\circ}$. Add the precipitate dropwise over the cells and mix gently. Incubate the cells overnight ( 16 hours) at $37^{\circ}$. The next day, remove medium from the plate, rinse cells with $5 \mathrm{ml}$ PBS, and add $7 \mathrm{ml}$ fresh medium. Collect the vector-containing medium after another 48 hours, centrifuge at $2000 \mathrm{~g}$ for $10 \mathrm{~min}$ to remove cellular debris and filter through a $0.45-\mu \mathrm{m}$ pore-size filter (Nalgene). Ultracentrifuge vector 
supernatants in 70-ml bottles (Beckman Coulter) at 45,000 $\mathrm{g}$ for $90 \mathrm{~min}$ at $4^{\circ}$. Resuspend pellets in $500 \mu \mathrm{l}$ medium by gentle vortexing for 2 hours at $4^{\circ}$. Spin down the debris at $2000 \mathrm{~g}$ for $5 \mathrm{~min}$ and store the concentrated vector particles at $-80^{\circ}$. Titer vector stocks on human fibrosarcoma HT1080 cells and assay for the presence of replication-competent virus as previously described (Ramezani and Hawley, 2002b; Ramezani and Hawley, 2003).

3. Coat 24-well non-tissue culture-treated plates (Lux Suspension Dish, Fisher Scientific, Catalog number ICNLX171099) with $2 \mu \mathrm{g} / \mathrm{cm}^{2}$ recombinant fibronectin fragment (RetroNectin, Takara Mirus Bio, Catalog number TAK_T100A). Culture $\mathrm{CD}^{2} 4^{+}$cells isolated as described in the previous section at a density of $1 \times 10^{6}$ cells/ $\mathrm{ml}$ for 24 hours in X-VIVO-15 serum-free medium (Fisher Scientific, Catalog number BW04-418Q) supplemented with 10\% BIT 9500 serum substitute (bovine serum albumin, insulin, and human transferrin; StemCell Technologies, Catalog number 09500), $100 \mu \mathrm{M} \beta$-mercaptoethanol, $100 \mathrm{ng} / \mathrm{ml} \mathrm{SCF}, 20 \mathrm{ng} / \mathrm{ml}$ TPO and $100 \mathrm{ng} / \mathrm{ml}$ Flt3 ligand, with or without $20 \mathrm{ng} / \mathrm{ml} \mathrm{IL}-3$ (all cytokines from PeproTech) at $37^{\circ}$ in a humidified atmosphere containing $5 \% \mathrm{CO}_{2}$. Transduce the cells with lentiviral vector particles $\left(2 \times 10^{6}\right.$ transducing units $/ \mathrm{ml}$; multiplicity of infection, 2$)$ in the presence of $4 \mu \mathrm{g} / \mathrm{ml}$ protamine sulfate (Sigma-Aldrich) (Ramezani et al., 2003; Ramezani and Hawley, 2002b; Ramezani and Hawley, 2003). Change the medium after 24 hours and continue culturing the cells.

4. Harvest the hematopoietic progenitor cells after an additional 48-72 hours of culture (Cell Dissociation Buffer, Invitrogen, Catalog number 13151-014), wash and resuspend in PBS containing 2\% FBS. Under the conditions employed, the majority of the cells retain the $\mathrm{CD} 34^{+}$phenotype (Ramezani et al., 2000). Isolate $\mathrm{GFP}^{+} \mathrm{YFP}^{+}$ cells to $>95 \%$ purity by fluorescence-activated cell sorting (Akimov et al., 2005; Cheng et al., 1997; Dorrell et al., 2000; Hawley et al., 2004). The YFP and GFP signals are separated with a $525 \mathrm{~nm}$ shortpass dichroic filter and collected with a 550/30 nm BP filter and a 510/20 nm BP filter, respectively (Omega Optical, Catalog number XCY-500).

5. Maintain the hematopoietic progenitor cells in continuous culture in X-VIVO-15 serum-free medium supplemented with $10 \%$ BIT 9500 serum substitute, $100 \mu \mathrm{M} \beta$ mercaptoethanol, $100 \mathrm{ng} / \mathrm{ml} \mathrm{SCF}, 20 \mathrm{ng} / \mathrm{ml}$ TPO and $100 \mathrm{ng} / \mathrm{ml} \mathrm{Flt3} \mathrm{ligand,} \mathrm{with} \mathrm{or}$ without $20 \mathrm{ng} / \mathrm{ml} \mathrm{IL}-3$ at $37^{\circ}$ in a humidified atmosphere containing $5 \% \mathrm{CO}_{2}$.

\section{Acknowledgements}

We gratefully acknowledge Reza Behnam, Michael Chase and Serguei Soukharev for technical assistance. This work was supported in part by National Institutes of Health grants R01HL65519, R01HL66305 and R24RR16209, and by the King Fahd Endowment Fund (The George Washington University School of Medicine and Health Sciences).

\section{References}

Abramson S, Miller RG, Phillips RA. The identification in adult bone marrow of pluripotent and restricted stem cells of the myeloid and lymphoid systems. J Exp Med 1977;145:1567-1579. [PubMed: 140917]

Akimov SS, Ramezani A, Hawley TS, Hawley RG. Bypass of senescence, immortalization, and transformation of human hematopoietic progenitor cells. Stem Cells 2005;23:1423-1433. [PubMed: 16144874]

Alexander WS, Roberts AW, Nicola NA, Li R, Metcalf D. Deficiencies in progenitor cells of multiple hematopoietic lineages and defective megakaryocytopoiesis in mice lacking the thrombopoietic receptor c-Mpl. Blood 1996;87:2162-2170. [PubMed: 8630375]

Ando K, Yahata T, Sato T, Miyatake H, Matsuzawa H, Oki M, Miyoshi H, Tsuji T, Kato S, Hotta T. Direct evidence for ex vivo expansion of human hematopoietic stem cells. Blood 2006;107:3371-3377. [PubMed: 16391011] 
Angelopoulou MK, Rinder H, Wang C, Burtness B, Cooper DL, Krause DS. A preclinical xenotransplantation animal model to assess human hematopoietic stem cell engraftment. Transfusion 2004;44:555-566. [PubMed: 15043572]

Arai F, Hirao A, Ohmura M, Sato H, Matsuoka S, Takubo K, Ito K, Koh GY, Suda T. Tie2/angiopoietin-1 signaling regulates hematopoietic stem cell quiescence in the bone marrow niche. Cell 2004;118:149161. [PubMed: 15260986]

Armstrong L, Stojkovic M, Dimmick I, Ahmad S, Stojkovic P, Hole N, Lako M. Phenotypic characterization of murine primitive hematopoietic progenitor cells isolated on basis of aldehyde dehydrogenase activity. Stem Cells 2004;22:1142-1151. [PubMed: 15579635]

Arndt-Jovin DJ, Jovin TM. Analysis and sorting of living cells according to deoxyribonucleic acid content. J Histochem Cytochem 1977;25:585-589. [PubMed: 70450]

Balazs AB, Fabian AJ, Esmon CT, Mulligan RC. Endothelial protein C receptor (CD201) explicitly identifies hematopoietic stem cells in murine bone marrow. Blood 2006;107:2317-2321. [PubMed: 16304059]

Bartolovic K, Balabanov S, Berner B, Buhring HJ, Komor M, Becker S, Hoelzer D, Kanz L, Hofmann WK, Brummendorf TH. Clonal heterogeneity in growth kinetics of CD34+CD38- human cord blood cells in vitro is correlated with gene expression pattern and telomere length. Stem Cells 2005;23:946957. [PubMed: 15941854]

Baum CM, Weissman IL, Tsukamoto AS, Buckle AM, Peault B. Isolation of a candidate human hematopoietic stem cell population. Proc Natl Acad Sci USA 1992;89:2804-2808. [PubMed: 1372992]

Bertoncello I, Bradley TR, Hodgson GS, Dunlop JM. The resolution, enrichment, and organization of normal bone marrow high proliferative potential colony-forming cell subsets on the basis of rhodamine-123 fluorescence. Exp Hematol 1991;19:174-178. [PubMed: 1995309]

Bertoncello I, Hodgson GS, Bradley TR. Multiparameter analysis of transplantable hemopoietic stem cells: I. The separation and enrichment of stem cells homing to marrow and spleen on the basis of rhodamine-123 fluorescence. Exp Hematol 1985;13:999-1006. [PubMed: 2865163]

Bertoncello I, Hodgson GS, Bradley TR. Multiparameter analysis of transplantable hemopoietic stem cells. II. Stem cells of long-term bone marrow-reconstituted recipients. Exp Hematol 1988;16:245249. [PubMed: 2896130]

Bertoncello I, Williams B. Hematopoietic stem cell characterization by Hoechst 33342 and rhodamine 123 staining. Methods Mol Biol 2004;263:181-200. [PubMed: 14976367]

Bhatia M, Bonnet D, Kapp U, Wang JCY, Murdoch B, Dick JE. Quantitative analysis reveals expansion of human hematopoietic repopulating cells after short-term ex vivo culture. J Exp Med 1997a; 186:619-624. [PubMed: 9254660]

Bhatia M, Bonnet D, Murdoch B, Gan OI, Dick JE. A newly discovered class of human hematopoietic cells with SCID-repopulating activity. Nat Med 1998;4:1038-1045. [PubMed: 9734397]

Bhatia M, Wang JC, Kapp U, Bonnet D, Dick JE. Purification of primitive human hematopoietic cells capable of repopulating immune-deficient mice. Proc Natl Acad Sci U S A 1997b;94:5320-5325. [PubMed: 9144235]

Bock TA, Orlic D, Dunbar CE, Broxmeyer HE, Bodine DM. Improved engraftment of human hematopoietic cells in severe combined immunodeficient (SCID) mice carrying human cytokine transgenes. J Exp Med 1995;182:2037-2043. [PubMed: 7500049]

Bonnet D. Haematopoietic stem cells. J Pathol 2002;197:430-440. [PubMed: 12115860]

Bonnet D, Bhatia M, Wang JC, Kapp U, Dick JE. Cytokine treatment or accessory cells are required to initiate engraftment of purified primitive human hematopoietic cells transplanted at limiting doses into NOD/SCID mice. Bone Marrow Transplant 1999;23:203-209. [PubMed: 10084250]

Bruno S, Gunetti M, Gammaitoni L, Perissinotto E, Caione L, Sanavio F, Fagioli F, Aglietta M, Piacibello W. Fast but durable megakaryocyte repopulation and platelet production in NOD/SCID mice transplanted with ex-vivo expanded human cord blood CD34+ cells. Stem Cells 2004;22:135-143. [PubMed: 14990853]

Campisi J. Senescent cells, tumor suppression, and organismal aging: good citizens, bad neighbors. Cell 2005;120:513-522. [PubMed: 15734683] 
Capel B, Hawley RG, Mintz B. Long- and short-lived murine hematopoietic stem cell clones individually identified with retroviral integration markers. Blood 1990;75:2267-2270. [PubMed: 2350573]

Cashman JD, Lapidot T, Wang JC, Doedens M, Shultz LD, Lansdorp P, Dick JE, Eaves CJ. Kinetic evidence of the regeneration of multilineage hematopoiesis from primitive cells in normal human bone marrow transplanted into immunodeficient mice. Blood 1997;89:4307-4316. [PubMed: 9192753]

Chaudhary PM, Roninson IB. Expression and activity of P-glycoprotein, a multidrug efflux pump, in human hematopoietic stem cells. Cell 1991;66:85-94. [PubMed: 1712673]

Chen CZ, Li M, de GD, Monti S, Gottgens B, Sanchez MJ, Lander ES, Golub TR, Green AR, Lodish HF. Identification of endoglin as a functional marker that defines long-term repopulating hematopoietic stem cells. Proc Natl Acad Sci U S A 2002;99:15468-15473. [PubMed: 12438646]

Cheng L, Du C, Lavau C, Chen S, Tong J, Chen BP, Scollay R, Hawley RG, Hill B. Sustained gene expression in retrovirally transduced, engrafting human hematopoietic stem cells and their lymphomyeloid progeny. Blood 1998;92:83-92. [PubMed: 9639503]

Cheng L, Du C, Murray D, Tong X, Zhang YA, Chen BP, Hawley RG. A GFP reporter system to assess gene transfer and expression in viable human hematopoietic progenitors. Gene Ther 1997;4:10131022. [PubMed: 9415306]

Christianson SW, Greiner DL, Hesselton RA, Leif JH, Wagar EJ, Schweitzer IB, Rajan TV, Gott B, Roopenian DC, Shultz LD. Enhanced human CD4+ T cell engraftment in beta2-microglobulindeficient NOD-scid mice. J Immunol 1997;158:3578-3586. [PubMed: 9103418]

Chute JP, Muramoto GG, Fung J, Oxford C. Soluble factors elaborated by human brain endothelial cells induce the concomitant expansion of purified human BM CD34+ CD38- cells and SCIDrepopulating cells. Blood 2005;105:576-583. [PubMed: 15345596]

Civin C, Strauss LC, Brovall C, Fackler MJ, Schwartz JF, Shaper JH. Antigenic analysis of haematopoiesis. III A haematopoietic progenitor cell surface antigen defined by a monoclonal antibody raised against KG1a cells. J Immunol 1984;133:157-165. [PubMed: 6586833]

Civin CI, Almeida-Porada G, Lee MJ, Olweus J, Terstappen LW, Zanjani ED. Sustained, retransplantable, multilineage engraftment of highly purified adult human bone marrow stem cells in vivo. Blood 1996a;88:4102-4109. [PubMed: 8943843]

Civin CI, Trischmann T, Kadan NS, Davis J, Noga S, Cohen K, Duffy B, Groenewegen I, Wiley J, Law P, Hardwich A, Oldham F, Gee A. Highly purified CD34-positive cells reconstitute hematopoiesis. J Clin Oncol 1996b;14:2224-2233. [PubMed: 8708711]

Conneally E, Cashman J, Petzer A, Eaves C. Expansion in vitro of transplantable human cord blood stem cells demonstrated using a quantitative assay of their lympho-myeloid repopulating activity in nonobese diabetic-scid/scid mice. Proc Natl Acad Sci U S A 1997;94:9836-9841. [PubMed: 9275212]

Dao MA, Arevalo J, Nolta JA. Reversibility of CD34 expression on human hematopoietic stem cells that retain the capacity for secondary reconstitution. Blood 2003;101:112-118. [PubMed: 12393633]

de Wynter EA, Buck D, Hart C, Heywood R, Coutinho LH, Clayton A, Rafferty JA, Burt D, Guenechea G, Bueren JA, Gagen D, Fairbairn LJ, Lord BI, Testa NG. CD34+AC133+ cells isolated from cord blood are highly enriched in long-term culture-initiating cells, NOD/SCID-repopulating cells and dendritic cell progenitors. Stem Cells 1998;16:387-396. [PubMed: 9831864]

Dorrell C, Gan OI, Pereira DS, Hawley RG, Dick JE. Expansion of human cord blood CD $34^{+} \mathrm{CD} 38^{-}$ cells in ex vivo culture during retroviral transduction without a corresponding increase in SCID repopulating cell (SRC) frequency: dissociation of SRC phenotype and function. Blood 2000;95:102-110. [PubMed: 10607692]

Eaker SS, Hawley TS, Ramezani A, Hawley RG. Detection and enrichment of hematopoietic stem cells by side population phenotype. Methods Mol Biol 2004;263:161-180. [PubMed: 14976366]

Fallon P, Gentry T, Balber A, Boulware D, Janssen W, Smilee R, Storms R, Smith C. Mobilized peripheral blood SSCloALDHbr cells have the phenotypic and functional properties of primitive haematopoietic cells and their number correlates with engraftment following autologous transplantation. $\mathrm{Br} \mathrm{J}$ Haematol 2003;122:99-108. [PubMed: 12823351]

Fox N, Priestley G, Papayannopoulou T, Kaushansky K. Thrombopoietin expands hematopoietic stem cells after transplantation. J Clin Invest 2002;110:389-394. [PubMed: 12163458] 
Gallacher L, Murdoch B, Wu DM, Karanu FN, Keeney M, Bhatia M. Isolation and characterization of human CD34(-)Lin(-) and CD34(+)Lin(-) hematopoietic stem cells using cell surface markers AC133 and CD7. Blood 2000;95:2813-2820. [PubMed: 10779426]

Gammaitoni L, Bruno S, Sanavio F, Gunetti M, Kollet O, Cavalloni G, Falda M, Fagioli F, Lapidot T, Aglietta M, Piacibello W. Ex vivo expansion of human adult stem cells capable of primary and secondary hemopoietic reconstitution. Exp Hematol 2003;31:261-270. [PubMed: 12644024]

Gao Z, Fackler MJ, Leung W, Lumkul R, Ramirez M, Theobald N, Malech HL, Civin CI. Human CD34 + cell preparations contain over 100-fold greater NOD/SCID mouse engrafting capacity than do CD34- cell preparations. Exp Hematol 2001;29:910-921. [PubMed: 11438214]

Gimeno R, Weijer K, Voordouw A, Uittenbogaart CH, Legrand N, Alves NL, Wijnands E, Blom B, Spits $\mathrm{H}$. Monitoring the effect of gene silencing by RNA interference in human CD34+ cells injected into newborn RAG2-/- gammac-/- mice: functional inactivation of $\mathrm{p} 53$ in developing T cells. Blood 2004;104:3886-3893. [PubMed: 15319293]

Glimm H, Eisterer W, Lee K, Cashman J, Holyoake TL, Nicolini F, Shultz LD, Von KC, Eaves CJ. Previously undetected human hematopoietic cell populations with short-term repopulating activity selectively engraft NOD/SCID-beta2 microglobulin-null mice. J Clin Invest 2001;107:199-206. [PubMed: 11160136]

Goldman JP, Blundell MP, Lopes L, Kinnon C, Di Santo JP, Thrasher AJ. Enhanced human cell engraftment in mice deficient in RAG2 and the common cytokine receptor gamma chain. $\mathrm{Br} \mathrm{J}$ Haematol 1998;103:335-342. [PubMed: 9827902]

Goodell MA, Brose K, Paradis G, Conner AS, Mulligan RC. Isolation and functional properties of murine hematopoietic stem cells that are replicating in vivo. J Exp Med 1996;183:1797-1806. [PubMed: 8666936]

Goodell MA, Rosenzweig M, Kim H, Marks DF, DeMaria M, Paradis G, Grupp SA, Sieff CA, Mulligan RC, Johnson RP. Dye efflux studies suggest that hematopoietic stem cells expressing low or undetectable levels of CD34 antigen exist in multiple species. Nat Med 1997;3:1337-1345. [PubMed: 9396603]

Gordon MY, Goldman JM, Gordon-Smith EC. 4-Hydroperoxycyclophosphamide inhibits proliferation by human granulocyte-macrophage colony-forming cells (GM-CFC) but spares more primitive progenitor cells. Leuk Res 1985;9:1017-1021. [PubMed: 4046632]

Guenechea G, Gan OI, Dorrell C, Dick JE. Distinct classes of human stem cells that differ in proliferative and self-renewal potential. Nat Immunol 2001;2:75-82. [PubMed: 11135582]

Gunji Y, Nakamura M, Osawa H, Nagayoshi K, Nakauchi H, Miura Y, Yanagisawa M, Suda T. Human primitive hematopoietic progenitor cells are more enriched in KITlow cells than in KIThigh cells. Blood 1993;82:3283-3289. [PubMed: 7694677]

Harrison DE. Competitive repopulation: a new assay for long-term stem cell functional capacity. Blood 1980;55:77-81. [PubMed: 6985804]

Harrison DE, Jordan CT, Zhong RK, Astle CM. Primitive hemopoietic stem cells: direct assay of most productive populations by competitive repopulation with simple binomial, correlation and covariance calculations. Exp Hematol 1993;21:206-219. [PubMed: 8425559]

Hashiyama M, Iwama A, Ohshiro K, Kurozumi K, Yasunaga K, Shimizu Y, Masuho Y, Matsuda I, Yamaguchi N, Suda T. Predominant expression of a receptor tyrosine kinase, TIE, in hematopoietic stem cells and B cells. Blood 1996;87:93-101. [PubMed: 8547681]

Hawley RG. Progress toward vector design for hematopoietic stem cell gene therapy. Curr Gene Ther 2001;1:1-17. [PubMed: 12109133]

Hawley RG, Lieu FHL, Fong AZC, Hawley TS. Versatile retroviral vectors for potential use in gene therapy. Gene Ther 1994;1:136-138. [PubMed: 7584069]

Hawley TS, Herbert DJ, Eaker SS, Hawley RG. Multiparameter flow cytometry of fluorescent protein reporters. Methods Mol Biol 2004;263:219-238. [PubMed: 14976369]

Hess DA, Meyerrose TE, Wirthlin L, Craft TP, Herrbrich PE, Creer MH, Nolta JA. Functional characterization of highly purified human hematopoietic repopulating cells isolated according to aldehyde dehydrogenase activity. Blood 2004;104:1648-1655. [PubMed: 15178579] 
Hess DA, Wirthlin L, Craft TP, Herrbrich PE, Hohm SA, Lahey R, Eades WC, Creer MH, Nolta JA. Selection based on CD133 and high aldehyde dehydrogenase activity isolates long-term reconstituting human hematopoietic stem cells. Blood 2006;107:2162-2169. [PubMed: 16269619]

Hill B, Rozler E, Travis M, Chen S, Zannetino A, Simmons P, Galy A, Chen B, Hoffman R. High-level expression of a novel epitope of CD59 identifies a subset of CD34+ bone marrow cells highly enriched for pluripotent stem cells. Exp Hematol 1996;24:936-943. [PubMed: 8690053]

Hiramatsu H, Nishikomori R, Heike T, Ito M, Kobayashi K, Katamura K, Nakahata T. Complete reconstitution of human lymphocytes from cord blood CD34+ cells using the NOD/SCID/ gammacnull mice model. Blood 2003;102:873-880. [PubMed: 12689924]

Hogan CJ, Shpall EJ, McNulty O, McNiece I, Dick JE, Shultz LD, Keller G. Engraftment and development of human CD34(+)-enriched cells from umbilical cord blood in NOD/LtSz-scid/scid mice. Blood 1997;90:85-96. [PubMed: 9207442]

Ishikawa F, Livingston AG, Wingard JR, Nishikawa S, Ogawa M. An assay for long-term engrafting human hematopoietic cells based on newborn NOD/SCID/beta2-microglobulin(null) mice. Exp Hematol 2002;30:488-494. [PubMed: 12031656]

Ito M, Hiramatsu H, Kobayashi K, Suzue K, Kawahata M, Hioki K, Ueyama Y, Koyanagi Y, Sugamura K, Tsuji K, Heike T, Nakahata T. NOD/SCID/gamma(c)(null) mouse: an excellent recipient mouse model for engraftment of human cells. Blood 2002;100:3175-3182. [PubMed: 12384415]

Ito T, Tajima F, Ogawa M. Developmental changes of CD34 expression by murine hematopoietic stem cells. Exp Hematol 2000;28:1269-1273. [PubMed: 11063875]

Iwama A, Hamaguchi I, Hashiyama M, Murayama Y, Yasunaga K, Suda T. Molecular cloning and characterization of mouse TIE and TEK receptor tyrosine kinase genes and their expression in hematopoietic stem cells. Biochem Biophys Res Commun 1993;195:301-309. [PubMed: 8395828]

Johnson LV, Walsh ML, Chen LB. Localization of mitochondria in living cells with rhodamine 123. Proc Natl Acad Sci U S A 1980;77:990-994. [PubMed: 6965798]

Jones RJ, Barber JP, Vala MS, Collector MI, Kaufmann SH, Ludeman SM, Colvin OM, Hilton J. Assessment of aldehyde dehydrogenase in viable cells. Blood 1995;85:2742-2746. [PubMed: 7742535]

Jones RJ, Collector MI, Barber JP, Vala MS, Fackler MJ, May WS, Griffin CA, Hawlekins AL, Zehnbauer BA, Hilton J, Colvin OM, Sharkis SJ. Characterization of mouse lymphohematopoietic stem cells lacking spleen colony-forming activity. Blood 1996;88:487-491. [PubMed: 8695796]

Jordan CT, Lemischka IR. Clonal and systemic analysis of long-term hematopoiesis in the mouse. Genes Dev 1990;4:220-232. [PubMed: 1970972]

Juliano RL, Ling V. A surface glycoprotein modulating drug permeability in Chinese hamster ovary cell mutants. Biochim Biophys Acta 1976;455:152-162. [PubMed: 990323]

Kamel-Reid S, Dick JE. Engraftment of immune-deficient mice with human hematopoietic stem cells. Science 1988;242:1706-1709. [PubMed: 2904703]

Kastan MB, Schlaffer E, Russo JE, Colvin OM, Civin CI, Hilton J. Direct demonstration of elevated aldehyde dehydrogenase in human hematopoietic progenitor cells. Blood 1990;75:1947-1950. [PubMed: 2337669]

Kaushansky K. Thrombopoietin: accumulating evidence for an important biological effect on the hematopoietic stem cell. Ann N Y Acad Sci 2003a;996:39-43. [PubMed: 12799280]

Kaushansky K. Thrombopoietin: a tool for understanding thrombopoiesis. J Thromb Haemost 2003b; 1:1587-1592. [PubMed: 12871295]

Kawashima I, Zanjani ED, maida-Porada G, Flake AW, Zeng H, Ogawa M. CD34+ human marrow cells that express low levels of Kit protein are enriched for long-term marrow-engrafting cells. Blood 1996;87:4136-4142. [PubMed: 8639771]

Keller G, Paige C, Gilboa E, Wagner EF. Expression of a foreign gene in myeloid and lymphoid cells derived from multipotent haematopoietic precursors. Nature 1985;318:149-154. [PubMed: 3903518]

Kiel MJ, Yilmaz OH, Iwashita T, Yilmaz OH, Terhorst C, Morrison SJ. SLAM family receptors distinguish hematopoietic stem and progenitor cells and reveal endothelial niches for stem cells. Cell 2005;121:1109-1121. [PubMed: 15989959] 
Kimura T, Minamiguchi H, Wang J, Kaneko H, Nakagawa H, Fujii H, Sonoda Y. Impaired stem cell function of CD34+ cells selected by two different immunomagnetic beads systems. Leukemia 2004;18:566-574. [PubMed: 14712284]

Kollet O, Peled A, Byk T, Ben-Hur H, Greiner D, Shultz L, Lapidot T. $\beta 2$ microglobulin-deficient $\left(\mathrm{B} 2 \mathrm{~m}^{\text {null })}\right.$ NOD/SCID mice are excellent recipients for studying human stem cell function. Blood 2000;95:3102-3105. [PubMed: 10807775]

Krause DS, Fackler MJ, Civin CI, May WS. CD34: structure, biology, and clinical utility. Blood 1996;87:1-13. [PubMed: 8547630]

Kyoizumi S, Baum CM, Kaneshima H, McCune JM, Yee EJ, Namikawa R. Implantation and maintenance of functional human bone marrow in SCID-hu mice. Blood 1992;79:1704-1711. [PubMed: 1558966]

Lang P, Bader P, Schumm M, Feuchtinger T, Einsele H, Fuhrer M, Weinstock C, Handgretinger R, Kuci S, Martin D, Niethammer D, Greil J. Transplantation of a combination of CD133+ and CD34+ selected progenitor cells from alternative donors. Br J Haematol 2004;124:72-79. [PubMed: 14675410]

Lapidot T, Pflumio F, Doedens M, Murdoch B, Williams DE, Dick JE. Cytokine stimulation of multilineage hematopoiesis from immature human cells engrafted in scid mice. Science 1992;255:1137-1141. [PubMed: 1372131]

Larochelle A, Vormoor J, Hannenberg H, Wang JCY, Bhatia M, Lapidot T, Moritz T, Murdoch B, Xiao XL, Kato I, Williams DA, Dick JE. Identification of primitive human hematopoietic cells capable of repopulating NOD/SCID mouse bone marrow: implications for gene therapy. Nat Med 1996;2:13291337. [PubMed: 8946831]

Leemhuis T, Yoder MC, Grigsby S, Aguero B, Eder P, Srour EF. Isolation of primitive human bone marrow hematopoietic progenitor cells using Hoechst 33342 and Rhodamine 123. Exp Hematol 1996;24:1215-1224. [PubMed: 8765497]

Lois C, Hong EJ, Pease S, Brown EJ, Baltimore D. Germline transmission and tissue-specific expression of transgenes delivered by lentiviral vectors. Science 2002;295:868-872. [PubMed: 11786607]

Lowry PA, Shultz LD, Greiner DL, Hesselton RM, Kittler EL, Tiarks CY, Rao SS, Reilly J, Leif JH, Ramshaw H, Stewart FM, Quesenberry PJ. Improved engraftment of human cord blood stem cells in NOD/LtSz-scid/scid mice after irradiation or multiple-day injections into unirradiated recipients. Biol Blood Marrow Transplant 1996;2:15-23. [PubMed: 9078350]

Ma Y, Ramezani A, Lewis R, Hawley RG, Thomson JA. High-level sustained transgene expression in human embryonic stem cells using lentiviral vectors. Stem Cells 2003;21:111-117. [PubMed: 12529558]

Madlambayan GJ, Rogers I, Kirouac DC, Yamanaka N, Mazurier F, Doedens M, Casper RF, Dick JE, Zandstra PW. Dynamic changes in cellular and microenvironmental composition can be controlled to elicit in vitro human hematopoietic stem cell expansion. Exp Hematol 2005;33:1229-1239. [PubMed: 16219546]

Matsubara A, Iwama A, Yamazaki S, Furuta C, Hirasawa R, Morita Y, Osawa M, Motohashi T, Eto K, Ema H, Kitamura T, Vestweber D, Nakauchi H. Endomucin, a CD34-like sialomucin, marks hematopoietic stem cells throughout development. J Exp Med 2005;202:1483-1492. [PubMed: 16314436]

Matsuoka S, Ebihara Y, Xu M, Ishii T, Sugiyama D, Yoshino H, Ueda T, Manabe A, Tanaka R, Ikeda Y, Nakahata T, Tsuji K. CD34 expression on long-term repopulating hematopoietic stem cells changes during developmental stages. Blood 2001;97:419-425. [PubMed: 11154218]

Matsuzaki Y, Kinjo K, Mulligan RC, Okano H. Unexpectedly efficient homing capacity of purified murine hematopoietic stem cells. Immunity 2004;20:87-93. [PubMed: 14738767]

Mazurier F, Doedens M, Gan OI, Dick JE. Rapid myeloerythroid repopulation after intrafemoral transplantation of NOD-SCID mice reveals a new class of human stem cells. Nat Med 2003;9:959963. [PubMed: 12796774]

Mazurier F, Fontanellas A, Salesse S, Taine L, Landriau S, Moreau-Gaudry F, Reiffers J, Peault B, Di Santo JP, de VH. A novel immunodeficient mouse model--RAG2 $\times$ common cytokine receptor gamma chain double mutants--requiring exogenous cytokine administration for human hematopoietic stem cell engraftment. J Interferon Cytokine Res 1999;19:533-541. [PubMed: 10386866] 
McAlister I, Wolf NS, Pietrzyk ME, Rabinovitch PS, Priestley G, Jaeger B. Transplantation of hematopoietic stem cells obtained by a combined dye method fractionation of murine bone marrow. Blood 1990;75:1240-1246. [PubMed: 1968771]

McCormack MP, Rabbitts TH. Activation of the T-cell oncogene LMO2 after gene therapy for X-linked severe combined immunodeficiency. N Engl J Med 2004;350:913-922. [PubMed: 14985489]

McCulloch EA, Till JE. Perspectives on the properties of stem cells. Nat Med 2005;11:1026-1028. [PubMed: 16211027]

McCune JM, Peault B, Streeter PR, Rabin L. Preclinical evaluation of human hematolymphoid function in the SCID-hu mouse. Immunol Rev 1991;124:45-62. [PubMed: 1804780]

Meyerrose TE, Herrbrich P, Hess DA, Nolta JA. Immune-deficient mouse models for analysis of human stem cells. BioTechniques 2003;35:1262-1272. [PubMed: 14682062]

Moayeri M, Hawley TS, Hawley RG. Correction of murine hemophilia A by hematopoietic stem cell gene therapy. Mol Ther 2005;12:1034-1042. [PubMed: 16226058]

Munger K, Baldwin A, Edwards KM, Hayakawa H, Nguyen CL, Owens M, Grace M, Huh K. Mechanisms of human papillomavirus-induced oncogenesis. J Virol 2004;78:11451-11460. [PubMed: 15479788]

Naldini L, Blomer U, Gallay P, Ory D, Mulligan R, Gage FH, Verma IM, Trono D. In vivo gene delivery and stable transduction of nondividing cells by a lentiviral vector. Science 1996;272:263-267. [PubMed: 8602510]

Naylor CS, Jaworska E, Branson K, Embleton MJ, Chopra R. Side population/ABCG2-positive cells represent a heterogeneous group of haemopoietic cells: implications for the use of adult stem cells in transplantation and plasticity protocols. Bone Marrow Transplant 2005;35:353-360. [PubMed: 15608658]

Ninos JM, Jefferies LC, Cogle CR, Kerr WG. The thrombopoietin receptor, c-mpl, is a selective surface marker for human hematopoietic stem cells. J Transl Med 2006;4:9. [PubMed: 16480521]

Nolta JA, Hanley MB, Kohn DB. Sustained human hematopoiesis in immunodeficient mice by cotransplantation of marrow stroma expressing human interleukin-3: analysis of gene transduction of long-lived progenitors. Blood 1994;83:3041-3051. [PubMed: 7514050]

Okamoto T, Aoyama T, Nakayama T, Nakamata T, Hosaka T, Nishijo K, Nakamura T, Kiyono T, Toguchida J. Clonal heterogeneity in differentiation potential of immortalized human mesenchymal stem cells. Biochem Biophys Res Commun 2002;295:354-361. [PubMed: 12150956]

Osawa M, Hanada K, Hamada H, Nakauchi H. Long-term lymphohematopoietic reconstitution by a single CD34-low/negative hematopoietic stem cells. Science 1996;273:242-245. [PubMed: 8662508]

Pearce DJ, Ridler CM, Simpson C, Bonnet D. Multiparameter analysis of murine bone marrow side population cells. Blood 2004;103:2541-2546. [PubMed: 14644998]

Perez LE, Rinder HM, Wang C, Tracey JB, Maun N, Krause DS. Xenotransplantation of immunodeficient mice with mobilized human blood CD34+ cells provides an in vivo model for human megakaryocytopoiesis and platelet production. Blood 2001;97:1635-1643. [PubMed: 11238102]

Petzer AL, Zandstra PW, Piret JM, Eaves CJ. Differential cytokine effects on primitive $\left(\mathrm{CD} 34^{+} \mathrm{CD} 38\right.$ ${ }^{-}$) human hematopoietic cells: novel responses to Flt3-ligand and thrombopoietin. J Exp Med 1996;183:2551-2558. [PubMed: 8676076]

Pfeifer A, Ikawa M, Dayn Y, Verma IM. Transgenesis by lentiviral vectors: lack of gene silencing in mammalian embryonic stem cells and preimplantation embryos. Proc Natl Acad Sci U S A 2002;99:2140-2145. [PubMed: 11854510]

Pflumio F, Izac B, Katz A, Shultz LD, Vainchenker W, Coulombel L. Phenotype and function of human hematopoietic cells engrafting immune-deficient CB17-severe combined immunodeficiency mice and nonobese diabetic-severe combined immunodeficiency mice after transplantation of human cord blood mononuclear cells. Blood 1996;88:3731-3740. [PubMed: 8916937]

Piacibello W, Sanavio F, Severino A, Dane A, Gammaitoni L, Fagioli F, Perissinotto E, Cavalloni G, Kollet O, Lapidot T, Aglietta M. Engraftment in nonobese diabetic severe combined immunodeficient mice of human CD34(+) cord blood cells after ex vivo expansion: evidence for the amplification and self-renewal of repopulating stem cells. Blood 1999;93:3736-3749. [PubMed: 10339480] 
Preffer FI, Dombkowski D, Sykes M, Scadden D, Yang YG. Lineage-negative side-population (SP) cells with restricted hematopoietic capacity circulate in normal human adult blood: immunophenotypic and functional characterization. Stem Cells 2002;20:417-427. [PubMed: 12351812]

Punzon I, Criado LM, Serrano A, Serrano F, Bernad A. Highly efficient lentiviral-mediated human cytokine transgenesis on the NOD/scid background. Blood 2004;103:580-582. [PubMed: 14512303]

Ramezani A, Hawley RG. Human immunodeficiency virus type 1-based vectors for gene delivery to human hematopoietic stem cells. Meth Mol Med 2003;76:467-492.

Ramezani, A.; Hawley, RG. Overview of the HIV-1 lentiviral vector system. In: Ausubel, F.; Brent, R.; Kingston, B.; Moore, D.; Seidman, J.; Smith, JA.; truhl, K., editors. Current Protocols in Molecular Biology. John Wiley \& Sons, Inc; New Jersey: 2002a. p. 16.21.1-16.21.15.

Ramezani, A.; Hawley, RG. Generation of HIV-1-based lentiviral vector particles. In: Ausubel, F.; Brent, R.; Kingston, B.; Moore, D.; Seidman, J.; Smith, JA.; truhl, K., editors. Current Protocols in Molecular Biology. John Wiley \& Sons, Inc; New Jersey: 2002b. p. 16.22.1-16.22.15.

Ramezani A, Hawley TS, Hawley RG. Performance- and safety-enhanced lentiviral vectors containing the human interferon- $\beta$ scaffold attachment region and the chicken $\beta$-globin insulator. Blood 2003;101:4717-4724. [PubMed: 12586614]

Ramezani A, Hawley TS, Hawley RG. Lentiviral vectors for enhanced gene expression in human hematopoietic cells. Mol Ther 2000;2:458-469. [PubMed: 11082319]

Sahovic EA, Colvin M, Hilton J, Ogawa M. Role for aldehyde dehydrogenase in survival of progenitors for murine blast cell colonies after treatment with 4-hydroperoxycyclophosphamide in vitro. Cancer Res 1988;48:1223-1226. [PubMed: 3342403]

Sato T, Laver JH, Ogawa M. Reversible expression of CD34 by murine hematopoietic stem cells. Blood 1999;8:2548-2554. [PubMed: 10515856]

Sauvageau G, Iscove NN, Humphries RK. In vitro and in vivo expansion of hematopoietic stem cells. Oncogene 2004;23:7223-7232. [PubMed: 15378082]

Scharenberg CW, Harkey MA, Torok-Storb B. The ABCG2 transporter is an efficient Hoechst 33342 efflux pump and is preferentially expressed by immature human hematopoietic progenitors. Blood 2002;99:507-512. [PubMed: 11781231]

Shizuru JA, Negrin RS, Weissman IL. Hematopoietic stem and progenitor cells: clinical and preclinical regeneration of the hematolymphoid system. Annu Rev Med 2005;56:509-538. [PubMed: 15660525]

Shmelkov SV, St CR, Lyden D, Rafii S. AC133/CD133/Prominin-1. Int J Biochem Cell Biol 2005;37:715-719. [PubMed: 15694831]

Shpall EJ, Jones RB, Bearman SI, Franklin WA, Archer PG, Curiel T, Bitter M, Claman HN, Stemmer SM, Purdy M, Myers SE, Hami L, Taffs S, Heimfeld S, Hallagan J, Berenson RJ. Transplantation of enriched CD34-positive autologous marrow into breast cancer patients following high-dose chemotherapy: influence of CD34-positive peripheral blood progenitors and growth factors on engraftment. J Clin Oncol 1994;12:28-36. [PubMed: 7505806]

Shultz LD, Lyons BL, Burzenski LM, Gott B, Chen X, Chaleff S, Kotb M, Gillies SD, King M, Mangada J, Greiner DL, Handgretinger R. Human lymphoid and myeloid cell development in NOD/LtSzscid IL2R gamma null mice engrafted with mobilized human hemopoietic stem cells. J Immunol 2005;174:6477-6489. [PubMed: 15879151]

Shultz LD, Schweitzer PA, Christianson SW, Gott B, Schweitzer IB, Tennent B, McKenna S, Mobraaten L, Rajan TV, Greiner DL, Leiter EH. Multiple defects in innate and adaptive immunologic function in NOD/LtSz-scid mice. J Immunol 1995;154:180-191. [PubMed: 7995938]

Sieburg HB, Cho RH, Dykstra B, Uchida N, Eaves CJ, Muller-Sieburg CE. The hematopoietic stem compartment consists of a limited number of discrete stem cell subsets. Blood 2006;107:23112316. [PubMed: 16291588]

Smogorzewska A, de Lange T. Regulation of telomerase by telomeric proteins. Annu Rev Biochem 2004;73:177-208. [PubMed: 15189140]

Solar GP, Kerr WG, Zeigler FC, Hess D, Donahue C, de Sauvage FJ, Eaton DL. Role of c-mpl in early hematopoiesis. Blood 1998;92:4-10. [PubMed: 9639492] 
Spangrude GJ, Heimfeld S, Weissman IL. Purification and characterization of mouse hematopoietic stem cells. Science 1988;241:58-62. [PubMed: 2898810]

Spangrude GJ, Johnson GR. Resting and activated subsets of mouse multipotent hematopoietic stem cells. Proc Natl Acad Sci USA 1990;87:7433-7437. [PubMed: 1977160]

Steward CG, Jarisch A. Haemopoietic stem cell transplantation for genetic disorders. Arch Dis Child 2005;90:1259-1263. [PubMed: 16301554]

Stewart, AK.; Dube, ID.; Hawley, RG. Gene marking and the biology of hematopoietic cell transfer in human clinical trials. In: Fairbairn, LJ.; Testa, N., editors. Blood Cell Biochemistry. 8. Hematopoiesis and Gene Therapy, Kluwer Academic/Plenum Publishers; New York: 1999. p. 243-268.

Storms RW, Goodell MA, Fisher A, Mulligan RC, Smith C. Hoechst dye efflux reveals a novel CD7(+) CD34(-) lymphoid progenitor in human umbilical cord blood. Blood 2000;96:2125-2133. [PubMed: 10979957]

Storms RW, Trujillo AP, Springer JB, Shah L, Colvin OM, Ludeman SM, Smith C. Isolation of primitive human hematopoietic progenitors on the basis of aldehyde dehydrogenase activity. Proc Natl Acad Sci USA 1999;96:9118-9123. [PubMed: 10430905]

Sutherland DR, Anderson L, Keeney M, Nayar R, Chin-Yee I. The ISHAGE guidelines for CD34+ cell determination by flow cytometry. J Hematother 1996;5:213-226. [PubMed: 8817388]

Szilvassy SJ, Humphries RK, Lansdorp PM, Eaves AC, Eaves CJ. Quantitative assay for totipotent reconstituting hematopoietic stem cells by a competitive repopulation strategy. Proc Natl Acad Sci USA 1990;87:8736-8740. [PubMed: 2247442]

Taussig DC, Pearce DJ, Simpson C, Rohatiner AZ, Lister TA, Kelly G, Luongo JL, net-Desnoyers GA, Bonnet D. Hematopoietic stem cells express multiple myeloid markers: implications for the origin and targeted therapy of acute myeloid leukemia. Blood 2005;106:4086-4092. [PubMed: 16131573]

Thomson JA, Itskovitz-Eldor J, Shapiro SS, Waknitz MA, Swiergiel JJ, Marshall VS, Jones JM. Embryonic stem cell lines derived from human blastocysts. Science 1998;282:1145-1147. [PubMed: 9804556]

Traggiai E, Chicha L, Mazzucchelli L, Bronz L, Piffaretti JC, Lanzavecchia A, Manz MG. Development of a human adaptive immune system in cord blood cell-transplanted mice. Science 2004;304:104107. [PubMed: 15064419]

Uchida N, Fujisaki T, Eaves AC, Eaves CJ. Transplantable hematopoietic stem cells in human fetal liver have a CD34(+) side population (SP) phenotype. J Clin Invest 2001;108:1071-1077. [PubMed: 11581308]

Ueda T, Tsuji K, Yoshino H, Ebihara Y, Yagasaki H, Hisakawa H, Mitsui T, Manabe A, Tanaka R, Kobayashi K, Ito M, Yasukawa K, Nakahata T. Expansion of human NOD/SCID-repopulating cells by stem cell factor, Flk2/Flt3 ligand, thrombopoietin, IL-6, and soluble IL-6 receptor. J Clin Invest 2000;105:1013-1021. [PubMed: 10749580]

Van Ziffle JA, Baerlocher GM, Lansdorp PM. Telomere length in subpopulations of human hematopoietic cells. Stem Cells 2003;21:654-660. [PubMed: 14595125]

Verstegen MM, Wognum AW, Wagemaker G. Thrombopoietin is a major limiting factor for selective outgrowth of human umbilical cord blood cells in non-obese diabetic/severe combined immunodeficient recipient mice. Br J Haematol 2003;122:837-846. [PubMed: 12930398]

Visser JW, Bol SJ, van den EG. Characterization and enrichment of murine hemopoietic stem cells by fluorescence activated cell sorting. Exp Hematol 1981;9:644-655. [PubMed: 6167457]

Vormoor J, Lapidot T, Pflumio F, Risdon G, Patterson B, Broxmeyer HE, Dick JE. Immature human cord blood progenitors engraft and proliferate to high levels in severe combined immunodeficient mice. Blood 1994;83:2489-2497. [PubMed: 7513200]

Vulliamy T, Marrone A, Goldman F, Dearlove A, Bessler M, Mason PJ, Dokal I. The RNA component of telomerase is mutated in autosomal dominant dyskeratosis congenita. Nature 2001;413:432-435. [PubMed: 11574891]

Wang J, Kimura T, Asada R, Harada S, Yokota S, Kawamoto Y, Fujimura Y, Tsuji T, Ikehara S, Sonoda Y. SCID-repopulating cell activity of human cord blood-derived CD34- cells assured by intra-bone marrow injection. Blood 2003;101:2924-2931. [PubMed: 12480697] 
Wang JC, Doedens M, Dick JE. Primitive human hematopoietic cells are enriched in cord blood compared with adult bone marrow or mobilized peripheral blood as measured by the quantitative in vivo SCIDrepopulating cell assay. Blood 1997;89:3919-3924. [PubMed: 9166828]

Weijer K, Uittenbogaart CH, Voordouw A, Couwenberg F, Seppen J, Blom B, Vyth-Dreese FA, Spits $\mathrm{H}$. Intrathymic and extrathymic development of human plasmacytoid dendritic cell precursors in vivo. Blood 2002;99:2752-2759. [PubMed: 11929763]

Wolf NS, Kone A, Priestley GV, Bartelmez SH. In vivo and in vitro characterization of long-term repopulating primitive hematopoietic cells isolated by sequential Hoechst 33342-rhodamine 123 FACS selection. Exp Hematol 1993;21:614-622. [PubMed: 8513861]

Yahata T, Ando K, Nakamura Y, Ueyama Y, Shimamura K, Tamaoki N, Kato S, Hotta T. Functional human T lymphocyte development from cord blood CD34+ cells in nonobese diabetic/Shi-scid, IL-2 receptor gamma null mice. J Immunol 2002;169:204-209. [PubMed: 12077246]

Yamaguchi H, Calado RT, Ly H, Kajigaya S, Baerlocher GM, Chanock SJ, Lansdorp PM, Young NS. Mutations in TERT, the gene for telomerase reverse transcriptase, in aplastic anemia. N Engl J Med 2005;352:1413-1424. [PubMed: 15814878]

Yasui K, Matsumoto K, Hirayama F, Tani Y, Nakano T. Differences between peripheral blood and cord blood in the kinetics of lineage-restricted hematopoietic cells: implications for delayed platelet recovery following cord blood transplantation. Stem Cells 2003;21:143-151. [PubMed: 12634410]

Yilmaz OH, Kiel MJ, Morrison SJ. SLAM family markers are conserved among hematopoietic stem cells from old and reconstituted mice and markedly increase their purity. Blood 2006;107:924-930. [PubMed: 16219798]

Yin AH, Miraglia S, Zanjani ED, meida-Porada G, Ogawa M, Leary AG, Olweus J, Kearney J, Buck DW. AC133, a novel marker for human hematopoietic stem and progenitor cells. Blood 1997;90:5002-5012. [PubMed: 9389720]

Yui J, Chiu CP, Lansdorp PM. Telomerase activity in candidate stem cells from fetal liver and adult bone marrow. Blood 1998;91:3255-3262. [PubMed: 9558381]

Zanjani ED, Almeida-Porada G, Flake AW. The human/sheep xenograft model: a large animal model of human hematopoiesis. Int J Hematol 1996;63:179-192. [PubMed: 8936332]

Zanjani ED, Almeida-Porada G, Livingston AG, Flake AW, Ogawa M. Human bone marrow CD34cells engraft in vivo and undergo multilineage expression that includes giving rise to CD34+ cells. Exp Hematol 1998;26:353-360. [PubMed: 9546319]

Zhang CC, Kaba M, Ge G, Xie K, Tong W, Hug C, Lodish HF. Angiopoietin-like proteins stimulate ex vivo expansion of hematopoietic stem cells. Nat Med 2006a;12:240-245. [PubMed: 16429146]

Zhang CC, Steele AD, Lindquist S, Lodish HF. Prion protein is expressed on long-term repopulating hematopoietic stem cells and is important for their self-renewal. Proc Natl Acad Sci U S A 2006b; 103:2184-2189. [PubMed: 16467153]

Zhou S, Morris JJ, Barnes Y, Lan L, Schuetz JD, Sorrentino BP. Bcrp1 gene expression is required for normal numbers of side population stem cells in mice, and confers relative protection to mitoxantrone in hematopoietic cells in vivo. Proc Natl Acad Sci U S A 2002;99:12339-12344. [PubMed: 12218177]

Zhou S, Schuetz JD, Bunting KD, Colapietro AM, Sampath J, Morris JJ, Lagutina I, Grosveld GC, Osawa M, Nakauchi H, Sorrentino BP. The ABC transporter Bcrp1/ABCG2 is expressed in a wide variety of stem cells and is a molecular determinant of the side-population phenotype. Nat Med 2001;7:1028-1034. [PubMed: 11533706]

Ziegler BL, Valtieri M, Almeida Porada G, De Maria R, Muller R, Masella B, Gabbianelli M, Casella I, Pelosi E, Bock T, Zanjani ED, Peschle C. KDR receptor: a key marker defining hematopoietic stem cells. Science 1999;285:1553-1558. [PubMed: 10477517]

Zijlmans JM, Visser JW, Kleiverda K, Kluin PM, Willemze R, Fibbe WE. Modification of rhodamine staining allows identification of hematopoietic stem cells with preferential short-term or long-term bone marrow-repopulating ability. Proc Natl Acad Sci U S A 1995;92:8901-8905. [PubMed: 7568040]

Zufferey R, Nagy D, Mandel RJ, Naldini L, Trono D. Multiply attenuated lentiviral vector achieves efficient gene delivery in vivo. Nat Biotechnol 1997;15:871-875. [PubMed: 9306402] 

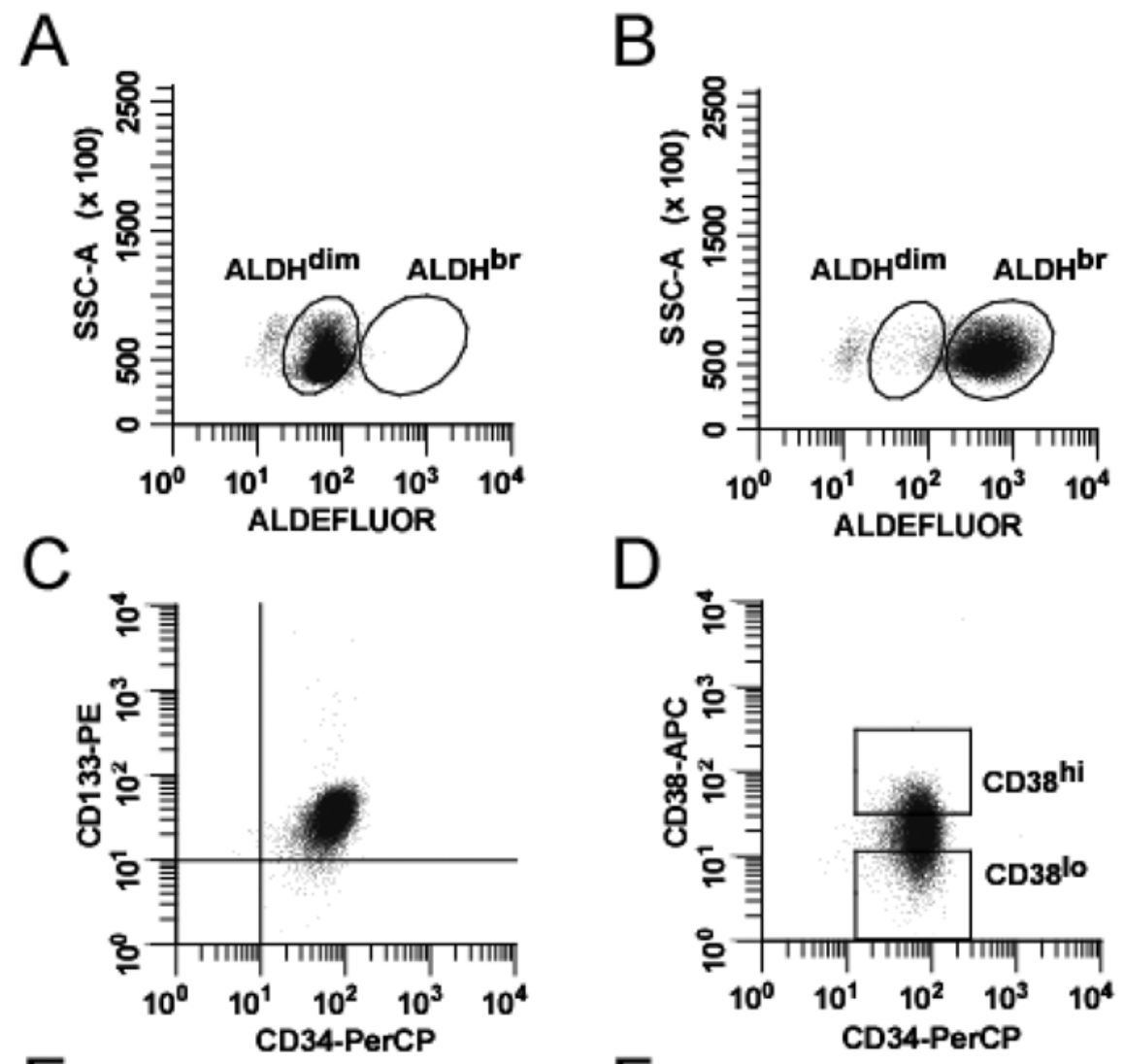

$\square$
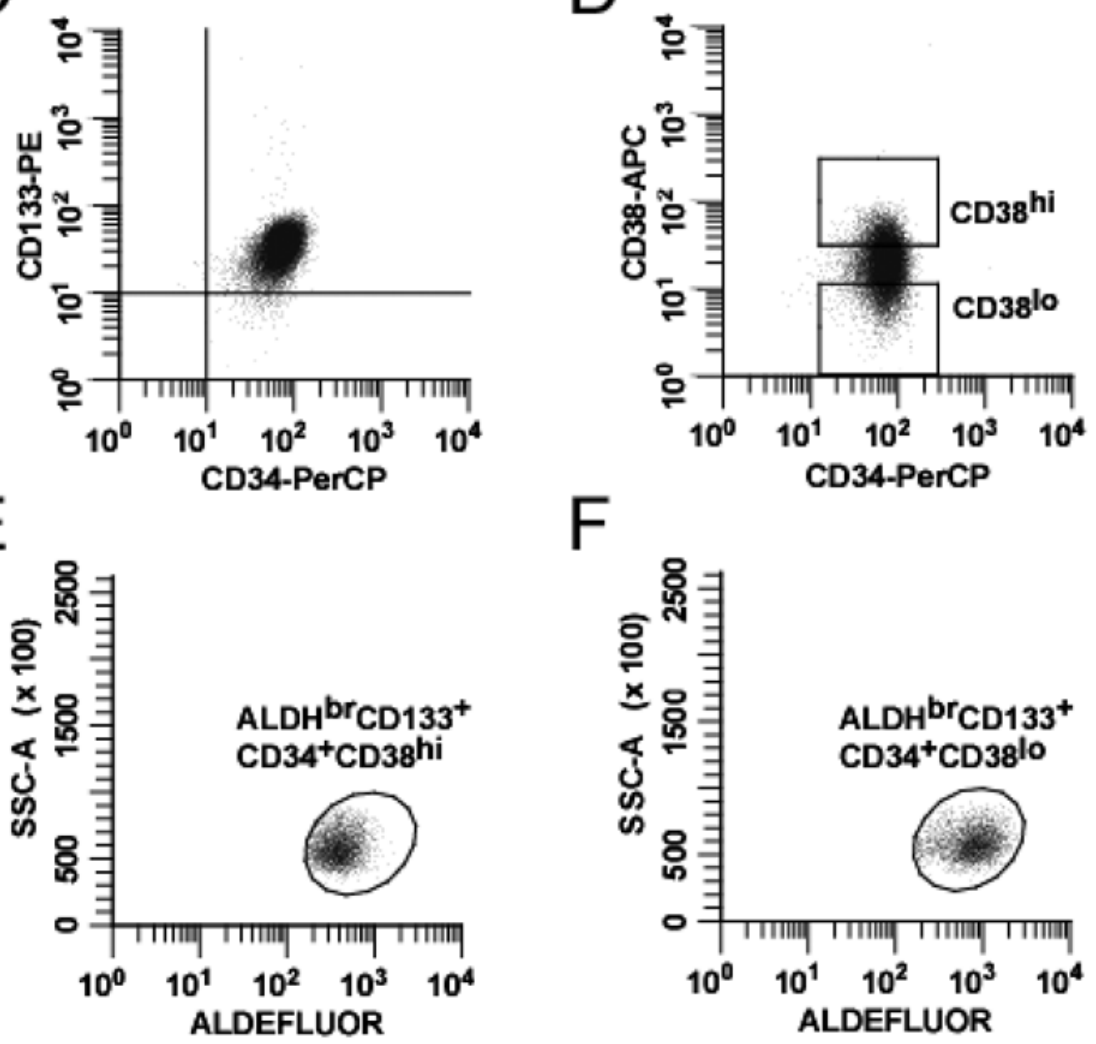

FIG. 1.

Flow cytometric characterization of human $\mathrm{CD} 133^{+}$cord blood cells expressing high levels of ALDH activity. (A) Negative control: Human cord blood cells highly enriched for CD133 expression $\left(>95 \% \mathrm{CD}^{\circ} 33^{+}\right)$exhibiting low side scatter $\left(\mathrm{SSC}^{\mathrm{lo}}\right)$ stained with BAAA (using the ALDEFLUOR ${ }^{\circledR}$ reagent) in the presence of DEAB, a potent ALDH inhibitor, show background levels of BAA fluorescence (ALDH ${ }^{\mathrm{dim}}$ ). Events to the left of the ALDH ${ }^{\mathrm{dim}}$ gate represent dead cells with no BAA fluorescence. (B) Human cord blood cells highly enriched for CD133 expression $\left(>95 \% \mathrm{CD}^{2} 33^{+}\right)$exhibiting low side scatter $\left(\mathrm{SSC}^{\mathrm{lo}}\right)$ stained with BAAA (using the ALDEFLUOR ${ }^{\circledR}$ reagent) in the absence of DEAB showing that almost all of the cells expressed high levels of ALDH activity (ALDH ${ }^{\mathrm{br}}$ ). (C) The vast majority of $\mathrm{ALDH}^{\mathrm{br}} \mathrm{CD} 133^{+}$cells coexpress the CD34 HSC surface antigen. (D-F) Flow cytometric analysis indicates that cells within the more primitive $\mathrm{CD} 133^{+} \mathrm{CD} 34^{+} \mathrm{CD} 38^{\mathrm{lo}}$ subpopulation express higher levels of 
ALDH activity than cells within the $\mathrm{CD} 133^{+} \mathrm{CD} 34^{+} \mathrm{CD} 38^{\text {hi }}$ subpopulation. (D) Gating strategy for $\mathrm{CD} 133^{+} \mathrm{CD} 34^{+} \mathrm{CD} 38^{\mathrm{hi}}$ and $\mathrm{CD} 133^{+} \mathrm{CD} 34^{+} \mathrm{CD} 38^{\text {lo }}$ subpopulations. (E)

$\mathrm{CD} 133^{+} \mathrm{CD} 34^{+} \mathrm{CD} 38^{\mathrm{hi}}$ cells are enriched for cells with the lowest levels of BAA fluorescence within the $\mathrm{ALDH}{ }^{\mathrm{br}}$ gate. $(\mathrm{F}) \mathrm{CD} 133^{+} \mathrm{CD} 34^{+} \mathrm{CD} 38^{\text {lo }}$ cells are enriched for cells with the highest levels of BAA fluorescence within the ALDH ${ }^{\text {br }}$ gate. Flow cytometry data was acquired on a FACSAria instrument (BD Biosciences) and analyzed with WinList 3D v6.0 pre-release software (Verity Software House). 

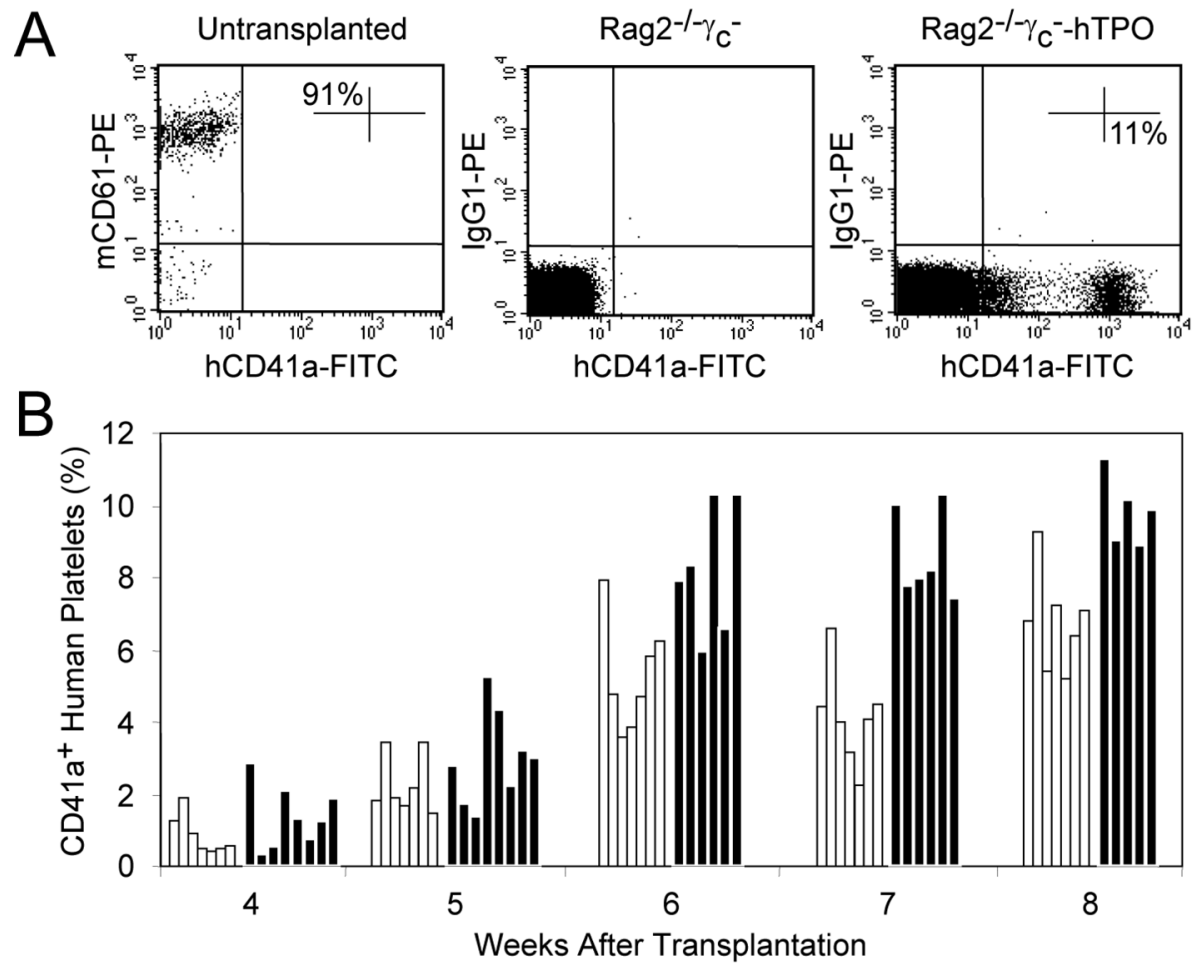

FIG. 2.

Human platelet production in peripheral blood of $\operatorname{Rag} 2^{-/-} \gamma_{\mathrm{c}}{ }^{-}$-hTPO mice transplanted with candidate human HSCs. (A) Sublethally irradiated (350 cGy) Rag $2^{-/-} \gamma_{\mathrm{c}}{ }^{-}$-hTPO and $\operatorname{Rag} 2^{-1-} \gamma_{\mathrm{c}}{ }^{-}$mice were transplanted with $5 \times 10^{5}$ human $\mathrm{CD} 34^{+}$cord blood cells. Human platelets were detected in the peripheral blood of all Rag2 $2^{-{ }^{-}} \gamma_{\mathrm{c}}{ }^{-}-\mathrm{hTPO}$ mice but not Rag $2^{-1-} \gamma_{c}{ }^{-}$mice by staining with an anti-human CD41a monoclonal antibody and gating on low forward and side scatter (platelet population gate). Shown are representative examples. Flow cytometry data was acquired on a FACSCalibur instrument and analyzed with CellQuest software (BD Biosciences). (B) Summary of the analysis of human CD41a ${ }^{+}$platelets within the platelet population in the peripheral blood of individual Rag2 ${ }^{-/-} \gamma_{\mathrm{c}}{ }^{-}$-hTPO mice 4 to 8 weeks after transplantation with $5 \times 10^{5}$ human $\mathrm{CD} 34^{+}$cells plus (dark bars) or minus (white bars) $1 \times 10^{6} \mathrm{CD}^{-} 4^{-} \mathrm{Lin}^{+}$accessory cells. 

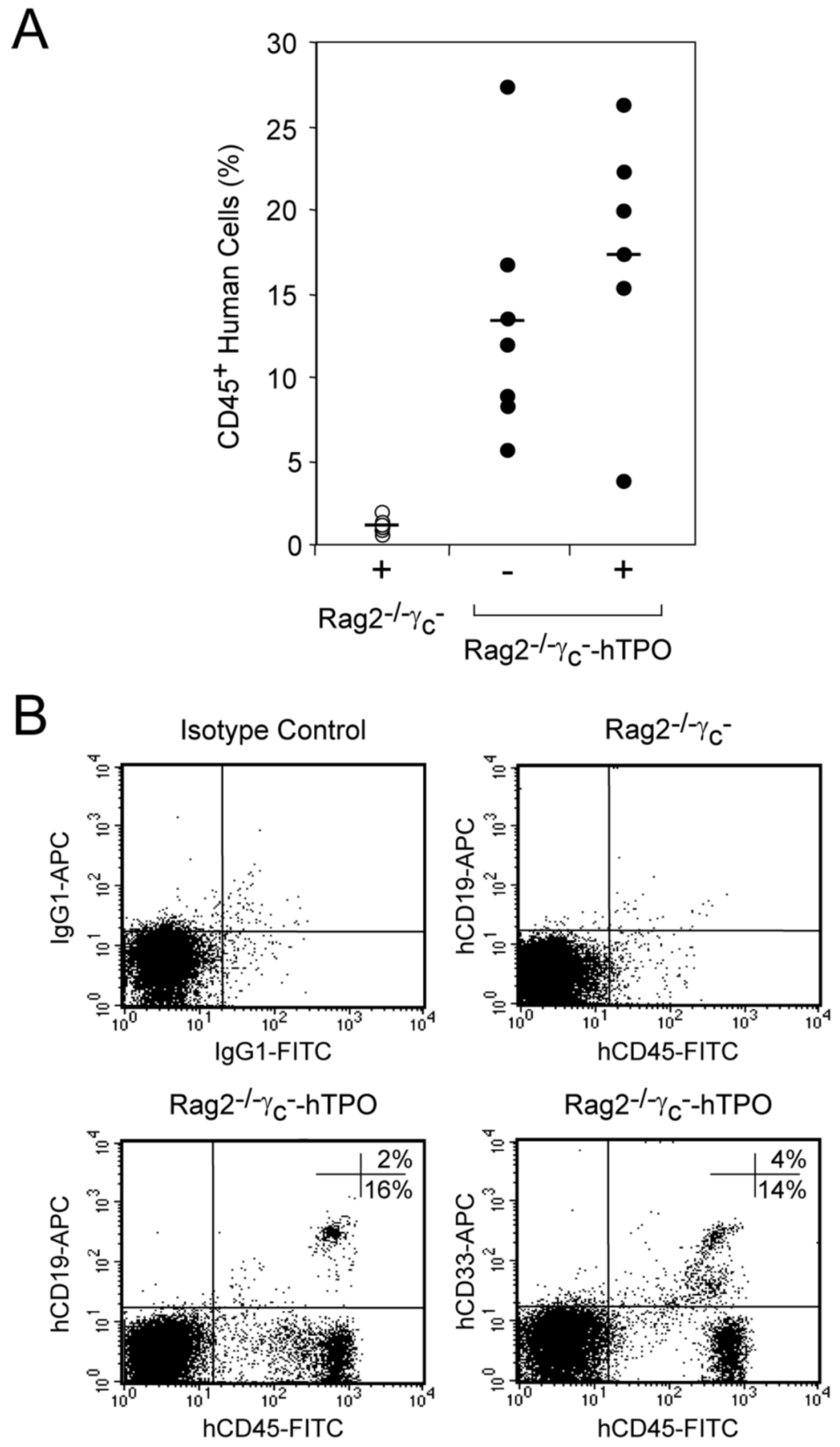

FIG. 3.

Multilineage human hematopoietic engraftment in the peripheral blood of Rag2 $2^{-/-} \gamma_{\mathrm{c}}{ }^{-}$-hTPO mice transplanted with candidate human HSCs. (A) Sublethally irradiated ( $350 \mathrm{cGy}$ ) mice were transplanted with $5 \times 10^{5}$ human CD34 ${ }^{+}$cord blood cells plus (+) or minus $(-) 1 \times 10^{6}$ $\mathrm{CD} 34^{-} \mathrm{Lin}^{+}$accessory cells. Shown is a summary of the percentages of $\mathrm{CD}^{2} 5^{+}$human cell engraftment in the peripheral blood of transplanted Rag $2^{-1-} \gamma_{\mathrm{c}}{ }^{-}$(open circles) and Rag2 ${ }^{-1-} \gamma_{\mathrm{c}}{ }^{-}$-hTPO (closed circles) mice 6 weeks after transplantation. Each circle represents data for an individual mouse and the horizontal lines indicate the mean levels of human cells. (B) Flow cytometric analyses showing percentages of human $\mathrm{CD} 45^{+} \mathrm{CD} 19^{+} \mathrm{B}$ cells and $\mathrm{CD} 45^{+} \mathrm{CD} 33^{+}$myeloid cells in the peripheral blood of a representative Rag2 ${ }^{-1-} \gamma_{\mathrm{c}}{ }^{-}$hTPO 
mouse at 6 weeks post-transplantation. Flow cytometry data was acquired on a FACSCalibur instrument and analyzed with CellQuest software (BD Biosciences). 


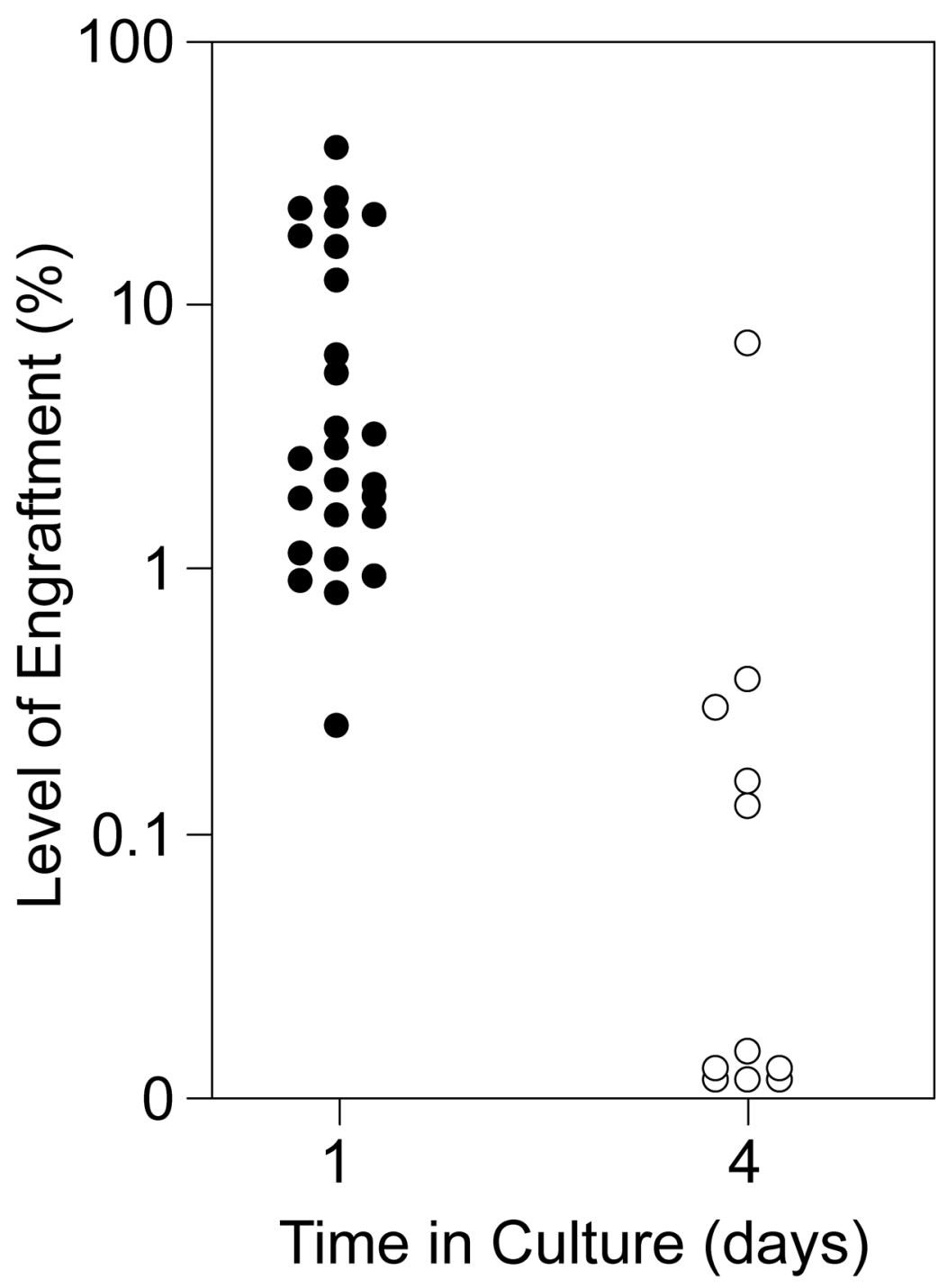

FIG. 4.

Loss of human hematopoietic repopulating potential during short-term in vitro culture of $\mathrm{CD} 34^{+}$cord blood cells. The potential of human $\mathrm{CD} 34^{+}$cord blood cells to engraft in the bone marrow of NOD/SCID mice was compared for cells cultured in vitro for 1 or 4 days in XVIVO-15 serum-free medium supplemented with $10 \%$ BIT 9500 serum substitute, $100 \mu \mathrm{M} \beta$ mercaptoethanol, $100 \mathrm{ng} / \mathrm{ml} \mathrm{SCF}, 20 \mathrm{ng} / \mathrm{ml}$ TPO and $100 \mathrm{ng} / \mathrm{ml}$ Flt3 ligand. The cells $(1.5 \times$ $10^{6}$ ) were harvested, mixed with $1 \times 10^{6} \mathrm{CD}^{-} 4^{-} \mathrm{Lin}^{+}$accessory cells and transplanted into sublethally irradiated (250 cGy) NOD/SCID mice. Twelve weeks after transplantation, the mice were euthanized and bone marrow cells collected for flow cytometric analysis. Human cells in the mouse bone marrow were detected after staining with anti-human CD45-PE-Cy5 (BD Biosciences Pharmingen, Catalog number 555484) monoclonal antibody. Transplantation of mice with $\mathrm{CD}_{3} 4^{+}$cord blood cells after 1 day of in vitro culture resulted in $~ 5 \%(0.5-50 \%)$ human hematopoietic cell engraftment (closed circles). The ability to repopulate NOD/SCID mouse bone marrow was significantly reduced (0-8\%, mean: $0.2 \%$ ) when the $\mathrm{CD} 34^{+}$cord blood cells were cultured in vitro for 4 days (open circles). 
Table 1

Characteristics of hTERT-plus HPV16 E6/E7-immortalized human cord blood-derived hematopoietic progenitor cell lines

\begin{tabular}{|c|c|c|}
\hline Cell Line & ET1a & ET2 \\
\hline $\begin{array}{l}\text { Cell Surface Phenotype }{ }^{a} \\
\text { Growth factor responsiveness } b \\
\text { Karyotype }^{c}\end{array}$ & $\begin{array}{c}\mathrm{CD} 133^{\mathrm{lo}} \mathrm{CD} 235 \mathrm{a}^{\mathrm{lo}} \mathrm{CD} 71^{+} \mathrm{CD} 203 \mathrm{c}^{+} \mathrm{CD} 33^{+} \mathrm{CD} 13^{+} \\
\text {SCF-dependent } \\
46, \mathrm{XY}, \operatorname{der}(22) \mathrm{t}(17 ; 22)[9]\end{array}$ & $\begin{array}{c}\mathrm{CD} 133^{\mathrm{lo}} \mathrm{CD} 235 \mathrm{a}^{\mathrm{lo}} \mathrm{CD} 71^{+} \mathrm{CD} 203 \mathrm{c}^{+} \mathrm{CD} 33^{+} \mathrm{CD} 13^{+} \\
\text {SCF-dependent } \\
45, \mathrm{XY}, \operatorname{der}(14) \mathrm{t}(9 ; 14), \operatorname{der}(19) \mathrm{t}(19 ; 22),-22[8]\end{array}$ \\
\hline \multicolumn{3}{|c|}{$\begin{array}{l}a \text { In addition to the CD133 cell surface antigen, candidate human HSCs have been suggested to express CD33 and CD13 (Taussig et al., } 2005 \text { ). } \\
b \text { The ET1a and ET2 human hematopoietic progenitor cell lines require SCF for survival and proliferation but grow optimally in the presence of SCF, } \\
\text { TPO, Flt3 ligand and IL-3. Based on growth factor responsiveness, the cell lines are presumed to express CD117 (c-Kit receptor) and CD123 (the low } \\
\text { affinity binding subunit of the IL-3 receptor). }\end{array}$} \\
\hline
\end{tabular}

